\title{
EL ESTILO DE ADÁN, PRIMER ARTISTA \\ Y PRIMERA OBRA DE ARTE. METAFÍSICA \\ Y ESTÉTICA EN EL NACIMIENTO DE \\ LA RAZÓN VITAL DE ORTEGA
}

\author{
FRANCESCO DE NIGRIS \\ Universidad Pontificia Comillas
}

\begin{abstract}
RESUMEN: La fundamental idea orteguiana de que «mi vida» es «razón», difiere radicalmente de la concepción fenomenológica de la razón que alumbra Husserl en Ideen, esencialmente fundada en el ser. La razón vital es teoría del hombre, que es su proyecto circunstancial; su estímulo argumental procede de una reflexión estética sobre todo orientada a la comprensión del realismo y del idealismo artísticos, y cuyas consecuencias filosóficas serán decisivas.
\end{abstract}

PALABRAS CLAVE: Ortega; vida; razón vital; arte; estética.

\section{The style of Adam, first artist and first masterwork. Metaphysics and aesthetics in the birth of Ortega's vital reason}

\begin{abstract}
The main orteguian's idea that «my life» is «reason», radically different from the phenomenological conception of reason that establishes Husserl in Ideen, mainly founded in being. Vital reason is theory of man as its circumstantial project; its unifying thread comes from an aesthetic reflection especially aimed at understanding realisms and idealisms, and whose philosophical consequences will be crucial.
\end{abstract}

KEY WORD: Ortega; life; vital reason; art; aesthetics.

«La ciencia moderna es de origen italo-francés; los alemanes crearon la ética, se justificaron por la gracia; los ingleses, por la política; a los españoles nos toca la justificación por la estética» Adán en el Paraíso. O.C. Tomo II, p. 61.

«Mi vida», "yo», no es «la conciencia» o «el yo», sino, como sostiene Ortega desde 1914, "todo ejecutándose», es decir, circunstancia proyectiva o, da lo mismo, proyecto circunstancial, en definitiva, perspectiva biográfica. Pensar en plena fecundidad filosófica esta idea, supone captar un criticismo de la razón originario y fundamental que no se limita a afirmar, como pudo hacer Escoto, el idealismo alemán o incluso más recientemente Heidegger, que la razón teórica se supedita a la práctica, esto es - al contrario de lo que expresó Santo Tomás-, que esse sequitur operari. Se trata de algo bien diferente: que la razón teórica es práctica. ¿Qué quiere decir esto? Cuando Ortega señala que nuestra vida es «todo ejecutándose», no pretende reconducir la filosofía a la vida pre-reflexiva en un sentido husserliano, que deriva de una teoría reflexiva que intenta dar razón del transcurso fáctico de una conciencia intencional, como generación temporal pasiva de la creencia de ser, fundamento unitario de la razón. La razón de la ejecutividad de la vida es teoría de lo imprevisible, no vivido, de ahí que «vida» significa algo no hecho, un quehacer que se está haciendo en un presente irrepetible, biográfico. 
Desde sus primeras obras Ortega va captando que la razón es la vida misma como teoría de su ejecutividad, y, por tanto, teoría de una verdad que no tiene principio y fin en el ser de las cosas, como si hubiese en ellas una esencia que ya está ahí y hay que desvelar. La verdad de la vida se hace auténtica o inauténticamente, en todo caso, creadoramente, en perspectiva: es el hombre. La antropología es la teoría intrínseca de la vida, es su tema poético en sentido radical, de ahí que cada vida, a partir de su estilo, hace humanidad. En otras palabras, la razón vital es conversión metafórica del individuo en el hombre, de ahí que es razón histórica, ejecutivamente narrativa, porque es intrínsecamente biográfica.

Siguiendo la fundamental advertencia de Ortega según la cual la crítica verdadera es aquella que potencia y completa la obra, en vez «de pulverizarla con una llovizna de anécdotas» ${ }^{1}$, he introducido una reflexión sobre el arte y la industria para ahondar en el sentido del realismo artístico, así como he adoptado el concepto de "pacto de ficción» para resaltar el tema poético de la razón vital y ponerlo en conexión con la forzosa ficción de totalidad que generan realismo e idealismo como razón de adecuación entre pensamiento y cosas a través del ser.

En las páginas que siguen, se ofrece una visión sistemática de algunas ideas de Ortega procedentes de sus primeras obras, para mostrar cómo su pensamiento, a diferencia de quienes lo han confundido con una reflexión fenomenológica, se alimenta de ideas variadas, debidamente orientadas a criticar la razón ontológica adecuacionista, y va sistemáticamente componiendo un método teórico ejecutivo que encuentra en la relación entre estética y gesto artístico su hilo conductor inspirador. Ortega considera el arte capaz de instalarse en el mismo método ejecutivo de la vida, y, por tanto, alumbrar el problema radical, creador que la anima y la compromete a ejecutarse dramática e individualmente. En particular modo, descubrir el sentido histórico del arte de vanguardia significa, por contraste, averiguar el «punto de vista humano» de «la realidad vivida».

Finalmente, este ensayo es insuficiente; prevé una segunda parte que lo complete abordando la decisiva teoría de los géneros literarios y de la temporalidad de la vida como tragicomedia, es decir, el nacimiento de la novela como fundación de una metafísica de esencial inspiración cervantina.

\section{TÉCNICA, POÉTICA Y LIRISMO EN LA FICCIÓN DEL ESTILO REALISTA}

Respecto del arte, Ortega distingue, en las Meditaciones del Quijote, el virtuosismo técnico (tékhne), «la poesía», como creación de un tema (poîein), y el lirismo, que define como la «proyección estética de la tonalidad

1 Meditaciones del Quijote, O. C. I, p.759, 760. Y en el mismo sentido desde 1902, en Glosas, Ibid. p. 7ss. Se utilizan las obras completas de Ortega, Taurus, Madrid, 2006, indicando los tomos en número romanos. Se añade el título de la obra tratada cuando no es evidente a partir del cuerpo del texto 
general de nuestros sentimientos» ${ }^{2}$. Ninguno de estos aspectos es separable -independientemente de lo que puede sugerir el «lirismo» como género artístico concreto-, y de su proporción se deriva una primera acepción de lo que significa el «estilo», categoría filosófica prístina en la obra de Ortega, que irá adquiriendo cada vez más vigor.

En el arte del gran escultor Ghiberti, el ideal renacentista de perfección técnica en la reproducción figurativa se pone al servicio de un tema poético ya dado, la escenificación bíblica. La verosimilitud plástica de las formas naturales plasmadas por el escultor en el relieve dorado de la puerta del Baptisterio descubre, de la mano de la criatura, la creación y la sabiduría divinas. En este caso, la creatividad del artista se sirve de un instrumento poético ya consolidado, solo concebible mediante una maestría técnica que eleva a cumbres líricas y funda la posibilidad misma de componer la obra bella. Respecto del arte medieval, el estilo renacentista aporta perspectiva, profundidad psicológica y retórica natural, de ahí que se le haya llamado «realista». Sin embargo, ¿qué significa el realismo como creación poética, considerando que se ha recurrido a este término para tantos otros estilos aparentemente dispares en la historia del arte, con sus propias técnicas y temples líricos?

Se ha admitido ingenuamente que el realismo en el arte significa la posibilidad de atenerse a las cosas exentas de recursos metafóricos, alusivos, ideales, en definitiva espirituales, que pudieran desviarnos de su interpretación primaria, impresionista, «material». A partir de esta concepción, indica Ortega, nace un perenne conflicto: "la "idea" o "sentido" de cada cosa y su "materialidad" aspiran a encajarse una en otra. Pero esto supone la victoria de una de ellas. Si la "idea" triunfa, la "materialidad" queda suplantada y vivimos alucinados. Si la materialidad se impone, y penetrando el vaho de la idea reabsorbe ésta, vivimos desilusionados ${ }^{3}$. Sin embargo, ¿desde cuándo nos hemos acostumbrado a creer que existe efectivamente este conflicto?

Sería impropio pensar que los griegos nos han educado a ver las cosas desde la sensibilidad, como si ella fuera la portadora indiscutible de una materialidad de impresiones que se organizan en pura res. Al contrario, la cosa griega es la sustantivación espiritual de la sensibilidad, siempre insuficiente para sí misma, incluso menesterosa, como llega a decir Aristóteles, de la imaginación y de la memoria, facultades noéticas del alma. El ê̂dos es el aspecto dominante, es decir, el percepto que es ya concepto, idea, pues pensar es ver correcta o espiritualmente (noein), en definitiva, revelar formas inteligibles a partir de la sensibilidad. ¿No deberíamos entonces admitir que el realismo es un ideal poético como otro que exige una determinada técnica para construir la res y detonar, según el canon figurativo correspondiente, la aspiración lírica del espectador, así como acabamos de ver en el caso de la verosimilitud del arte renacentista? ¿No corresponde en esta al relato bíblico ser el fermento poético

O.C. I, p. 817.

Ibid. p. 813. 
que estimula el ideal técnico del artista, cuyo talento reivindica y exalta la criatura entre todas las cosas, siendo ella misma la perfección primera y última de la naturaleza?

Cuenta agudamente Ortega que «Solía Leonardo de Vinci poner a sus alumnos frente a una tapia, con el fin de que se acostumbraran a intuir en las formas de las piedras, en las líneas de sus junturas, en los juegos de sombra y claridad, multitud de formas imaginarias. Platónico en el fondo de su ser, buscaba en la realidad Leonardo sólo el paracleto, el despertador del espíritu» ${ }^{4}$. Realismo es, por tanto, un esfuerzo poético más, un esfuerzo de concreción que niega la volubilidad del espíritu, la variabilidad de sus interpretaciones y persigue el aspecto dominante como visión de lo descarnado e inerte. «La cosa inerte y áspera escupe de sí cuantos "sentidos" queramos darle: está ahí, frente a nosotros, afirmando su muda, terrible materialidad frente a todos los fantasmas. He ahí lo que llamamos realismo: traer las cosas a una distancia, ponerlas bajo una luz, inclinarlas de modo que se acentúe la vertiente de ellas que baja hacia la pura materialidad $»^{5}$. Realismo, concluye Ortega, no es «acentuación de la res, de las cosas, sino de la apariencia de las cosas. Mejor fuera denominarlo aparentismo, ilusionismo, impresionismo» ${ }^{6}$.

Ingenuo y desorientador sería creer que el tema poético del realismo es la duplicación de la cosa, la búsqueda del camino de plena adecuación a ella. Replicar las cosas como tema poético lleva a la hipertrofia de la técnica, a la eliminación del «lirismo», a menos que este se interprete como la emoción del experto que admira en el proceso industrial la eficacia de la máquina y la aptitud del material. Mas el espectador de la industria no es buscado. El espectáculo de la producción en escala no ofrece otro tema poético que el implacable avance de la técnica al servicio de lo útil. Y, más aún, la re-presentación de la cosa industrial no nace de un mundo contingente, que es uno entre otros infinitos, posibles, una ficción por principio sorprendente. Su lógica, al contrario, es previsora y previsible, avance seguro hacia la manufactura, la cual, por otra parte, no aspira a exhibirse sino a venderse. Por eso mismo, el paisaje industrial ha desterrado al hombre, quien entorpece el ritmo de producción. Es la cosa, en cuanto producto logrado, la que prevé el forzoso espectáculo de su producción, de ahí que la creatividad solo parcialmente se encuentra en ella: como invención de un tipo, de una muestra, y de la construcción de un nuevo proceso que la reproduzca. El producto en escala restringe la creatividad de la ficción a lo útil, provechoso, lucrativo. Si en el arte lo contrario de lo bello es lo feo, eliminado el lirismo, el canon de belleza del producto se contradice con lo defectuoso, con el desecho.

No es difícil entender, entonces, por qué la labor del artesano, tan penosa en sus orígenes, ha ganado frente a la fabricación industrial cotas de lirismo

Ibid. p. 813.

5 Ibid.

$6 \quad$ Ibid. p. 780. 
impensables antaño. El desperfecto es signo de valía, lo deforme da prestigio al producto que se exhibe y se sustrae a la ley del mercado de bienes útiles, porque el gusto «no tiene precio». La técnica del artesano descubre un cierto modo de vida o tipo de hombre, en cuya obra se halla el rastro del individuo que se define en ella. La obra de artesanía es aún hija de una intimidad, se ha gestado como unidad entre otras posibles, cada una diferente, irreproducible, imaginada e improvisada a la vez. Con el artesano, intermediario entre el arte y la industria, llegamos a dar con una primera diferencia radical entre la obra de arte y el producto, que, además, será reveladora para comprender la verdadera índole del arte realista y, finalmente, captar el sentido más profundo del concepto de estilo que utiliza Ortega. La raíz del realismo es la ficción, pero este, en cuanto estilo artístico, exige un pacto.

\section{PACTO DE FICCIÓN Y CUERPo DRAMÁTICO DEL ARTE}

En el mundo de la industria se intenta eliminar lo humano por su ineficiencia técnica y sustituirlo con la máquina, de ahí que en vez de espectadores se buscan supervisores y programadores. La programación es el único punto de contacto con la vida artística, si bien su arte consiste, precisamente, en que el hombre programa prescindir de sí, desaparecer del proceso productivo. Programar es deshumanizar. El puro método del arte, sin embargo, tiene su inicio en un ofrecimiento en forma de invitación a aceptar un pacto de ficción: se crea un mundo en que nace la obra y se invita a acceder a él para hacer morada, admirar y entretenerse. El artesano todavía entretiene, imagina su obra. Esta se va gestando en sus manos para el espectador que, curioso de un arte hodierna o fenecida, es retenido en un mundo que ya no existe o pronto desaparecerá. El arte exige soñar, pero despiertos. Si la vida onírica postula la pérdida de la conciencia que fuerza a aceptar por real lo soñado, de ahí que el acceso a su ficción - a veces a nuestro pesar en las pesadillas- no implica ningún pacto, pues fisiológicamente lo impone, el arte, al contrario, es sueño de mediodía en que nos entregamos con lucidez a un mundo innecesario para quedarnos necesariamente en él si la obra nos atrapa, si nos hace mundo y personajes suyos. La radicalidad del pacto de ficción, que mide la capacidad del espectador para entregarse a la obra, a imaginarse sin límite de mundo en ella, es la primera frontera entre el arte y la industria. Esta se limita a la reciprocidad entre empresa y cliente, producto y deshecho, ganancia y mercado; la confianza que se exigen las partes, ventilada en la publicidad —alma del comercio-, se funda en la fiabilidad del producto en que se agota la imaginación técnica.

Volvamos ahora al pensamiento de Ortega y preguntémonos, respecto del arte realista: ¿en qué consiste su estilo? Por lo pronto, el realismo artístico como espectáculo que entretiene al hombre, invitándolo a permanecer y recrearse en su mundo, estriba en la tematización poética de lo que entiende por realidad. Ya vimos, según palabras de Ortega, que hay unos rasgos comunes 
respecto de lo que suele llamarse real, como la gravedad, la inercia, la aspereza, la firmeza..., es decir, todo aquello que niega lo voluble, lo innecesario, lo espiritual...; pero esto quiere decir que no interesan tanto al realismo las realidades, como si tuviera que instruirnos respecto de ellas, en cada ámbito, con un catálogo de cosas que pertenece a la región ontológica de «lo real», que así podríamos catalogar descriptivamente - en filosofía - desde una conciencia transcendental fenomenológica. Al contrario, lo que interesa al realismo es la representación de la realidad que hay en las realidades, o sea, la función genérica de la realidad que determina una idea de lo que es real.

La literatura realista, nos recuerda Ortega, se alimenta del mito en la medida en que busca su desmoronamiento. En sus novelas los personajes son inercia y desolación frente al altivo ademán estatuario del héroe mítico; en su narración, la cotidianidad confirma inexorablemente la presencia de lo que hay y rechaza la ilusión fabulada de lo que podría haber. ¿Qué fascinación sobre el espectador cabe imaginar que ejercen, entonces, los personajes de la literatura realista? «Los personajes de la novela — responde Ortega- carecen de atractivo. ¿Cómo es posible que su representación nos conmueva? Y, sin embargo, es así: no ellos, no las realidades nos conmueven, sino su representación, es decir, la representación de la realidad de ellos. Esta distinción es, en mí entender, decisiva: lo poético de la realidad no es la realidad como esta o aquella cosa, sino la realidad como función genérica. Por eso, en rigor, es indiferente qué objetos elija el realista para describirlos. Cualquiera es bueno, todos tienen un halo imaginario en torno. Se trata de mostrar bajo él la pura materialidad. Vemos en ella lo que tiene de instancia última, de poder crítico, ante quien se rinde la pretensión de todo lo ideal, de todo lo querido e imaginado por el hombre a declararse suficiente ${ }^{7}$ ».

El realismo fuerza a elegir lo real y revela su otra cara que pretende negar, alimentándose de ella: lo ideal, lo fantástico, hiperbólico, en definitiva, lo improbable o resueltamente imposible. Real es lo firme, asumible por adecuado, verosímil, presente, seguro y verdadero en cuanto sustrato reiterado, permanente de las cosas; lo que los griegos llamaron su ser, y Aristóteles, como su maestro Platón, su aspecto dominante (eîdos, idea). El ser de las cosas, su función de realidad, es el instrumento de poetización del realismo sobre el que construye su pacto de ficción y que modula los distintos estilos, cada uno a su modo, realistas. Sin embargo, habrá que preguntarse: ¿cómo es posible crear un pacto de ficción sobre la realidad y que tiene como tema la realidad misma? Precisamente porque la afirmación de lo real determina lo que es ideal; con aquel se juzga este en su grado de realización posible, generando un drama. Si la epokhé fenomenológica neutraliza la creencia del ser, el arte realista la transforma en idea, la tematiza poéticamente, y con esa idea de realidad forja un pacto de ficción, desvelando, así, que la realidad es idea, que realismo es idealismo, es decir, siempre ficción de realidad.

\footnotetext{
$7 \quad$ Ibid. p. 814.
} 
«La realidad», entonces, funciona tanto en el naturalismo renacentista como en la comedia, en el verismo pictórico como en el realismo mágico..., porque lo real y lo ideal son inseparables y difieren solo en el acento metafísico que forja su drama, según acabe dominando una ficción u otra.

Hay un estilo artístico que desenmascara implacablemente la ficción realista, que pone al desnudo su secreto afán de afirmar una idea de lo real denunciando la idealidad de todas las demás. Ese estilo es el mimo, forma extrema de realismo artístico en que se pide aceptar lo inaceptable: que la vida pueda ser replicada, que la persona sea biográficamente clonada. En el mimo se consuma la burla, ya que la realidad se desvela insoportablemente ideal y la generosidad del espectador a la hora de aceptar el pacto de ficción se ve ridiculizada porque - y aquí está la clave- se hace tema poético el pacto mismo y la ficción siempre vuelve sobre sí, excluyendo al espectador. Aun así, la irrespetuosidad del mimo no disminuye su interés artístico. A algunos sigue interesando, entreteniendo, atrapando, según los casos. Se mezcla en él una forma de arte tan popular como conceptual, tan obvia y aburrida como irónica y sutil. En todo momento su fuerza lírica vacila entre lo pretencioso y lo sublime, cargando enteramente sobre el talento del artista el desenlace que define su destino. La silenciosa sabiduría del mimo de cara a desvelar la ficción del realismo estriba en que su tema poético es la ficción de una ficción, pues revela que la realidad ejecutiva que es mi vida, supuestamente no reflejada por el arte, es, en el fondo, también ficción. El buen mimo, lejos de burlarse del espectador le sugiere que no es más necio que cualquier transeúnte, y, además, le conciencia de que la vida misma es arte espontáneo, pacto tácito de realización de posibilidades o ideales. Cada uno acepta imaginarse durante el día, repetir acciones valiosas, seguir ejemplos, o, en los peores casos, dejarse conducir como una marioneta por el tráfago cotidiano. El hombre de a pié, al contrario del amante del arte, tiene que aceptar forzosamente el drama de la vida, su esfuerzo de realización, pero sin saberlo, y, sobre todo, sin haber ensayado previamente ese arte espontáneo del vivir en el arte reflexivo que puede auxiliarlo y encauzarlo: la cultura.

Dejamos así esbozado de qué modo el arte es cultura. Veamos ahora una última relevante diferencia entre el arte realista y la producción industrial.

Tanto el arte comola industria son trabajos de imaginación, pero aquella, hemos dicho, no tiene límite de mundos, sus productos transcienden la imaginación y se filian en la fantasía. Aún así, por muy irreales que sean los mundos fantásticos y sus personajes, también la ficción artística tiene que realizar algo de vida concreta en ellos, de suerte que la peculiaridad del arte en sentido estricto es que esta realización, a diferencia del propósito buscado por la industria, es insegura, dramática. Si hemos definido la industria como técnica que busca la duplicación, en realidad, tal ideal conlleva la aniquilación de la técnica en favor del programa, de lo que no admite fallo, de lo que no ofrece margen de mejora respecto de un tipo ya plasmado, de suerte que la técnica para el proceso de fabricación se revela solo cuando falla, cuando hay un problema en la cadena de producción o, ya fuera de ella, en un cambio de producto que exige otra planificación. La industria es aniquilación de la técnica porque la suplanta asegurándola como 
proceso mecánico, de ahí que no se aprehende un procedimiento sino que se ejecuta excluyendo la posibilidad del error. Solo el cuerpo humano, no el cuerpo mecánico, es técnico, porque es falible en cada uno de sus actos y exige entrenamiento, repetición, aprendizaje, acercamiento a un ideal de ficción que siempre implica una realización insegura, una aventura, es decir, el porvenir de lo proyectado como riesgo. Esto nos lo ha confirmado el artesano, en cuya obra todavía hay posibilidad de fallo, en cuyo esfuerzo hay drama e imaginación, o, más aún, fantasía. En su producto se entremezclan forzosamente la utilidad y el adorno, la técnica y el virtuosismo de una poetización aún libre.

Quizá pocos más que Levinas han visto con claridad y agudeza esta condición del cuerpo humano frente a la máquina. Un cuerpo, el del hombre, que no es cuerpo vivo (Leib) en el mero sentido aperceptivo sensible, cinestésico, sino obra de imaginación, se imagina imaginando mundo, con licencia de fantasía. A este cuerpo habrá que llamarle biográfico, si bien, para ello, es necesario descubrir precisamente el drama de su carne, su pacto de ficción. Afirma Levinas en Totalité et infini: "La main est par essence tâtonnement et emprise. Le tâtonnement n'est pas une action techniquement imparfaite, mais la condition de toute technique. [...] Seul un être doué d'organes peut concevoir une finalité technique, un rapport entre la fin et l'outil. La fin est un terme que la main cherche en risquant de le rater. Le corps en tant que possibilité d'une main et sa corporéité tout entière peut se substituer à la main existe dans la virtualité de ce mouvement se portant vers l'outil» ${ }^{8}$. El tanteo de una mano, incluso cuando repite un movimiento ensayado, es falible; si su gesto fuera seguro, automático, no habría técnica, de ahí que toda técnica, incluso la de la industria, en realidad, se inicia y deriva de un gesto humano. La máquina es técnica porque todavía deriva su funcionamiento de la posibilidad de un fallo humano que la ha iniciado, programado, de ahí que, como anticipamos, necesita ser supervisada. Su drama es derivado. El arte, en sentido estricto, sin embargo, es aventura, porque busca o se atiene a un ideal y forja la técnica para sublimarlo, escenificando en una atmosfera lírica en que se representa la belleza de la empresa.

Cuerpo vivo, carne, entonces, implica una posibilidad de mundo, porque la posibilidad es la de quien realiza siempre una idea en él; y esa idea distingue precisamente la técnica del hombre de la del animal, así como sus respectivas corporeidades.

Para Ortega, la falibilidad del movimiento de la vida, desde las Meditaciones del Quijote, se expresa radicalmente por la inclusión del cuerpo en la circunstancia9.

\footnotetext{
8 Levinas, E., Totalité et infini, Kluwer Academic, Paris, 1971, p. 178.

9 «La ciencia biológica más reciente estudia el organismo vivo como una unidad compuesta del cuerpo y su medio particular: de modo que el proceso vital no consiste sólo en una adaptación del cuerpo a su medio, sino también en la adaptación del medio a su cuerpo. La mano procura amoldarse al objeto material a fin de apresarlo bien; pero, a la vez, cada objeto material oculta una previa afinidad con una mano determinada» (O.C. I, p. 757). Cuerpo y medio son inseparables, mi cuerpo es también circunstancia, como volverá a repetir Ortega en su obra madura (Cf. por ejemplo, Meditaciones sobre la técnica: «Ese
} 
La individualidad humana encuentra su salida «natural hacia el universo» desde la circunstancia y, además — dándose esta en perspectiva-, desde lo más próximo de ella: «este sector de realidad circunstante [la sierra de Guadarrama] forma la otra mitad de mi persona: sólo al través de él puedo integrarme y ser plenamente yo mismo ${ }^{10}$. Esta integración entre yo y circunstancia no es solo ni fundamentalmente esfuerzo del pensamiento teórico, que precisamente busca entenderla y hacerse su portavoz, sino que consiste en la tarea de salvación personal que es mi vida como razón proyectiva o ejecutiva de la circunstancia. Se trata, la vida, por tanto, de un movimiento falible, dramático, inseguro, peligroso. "Integrarme en la circunstancia» o «reabsorberla», como se dice en otro lugar, «es el destino concreto del hombre», es la facticidad de salvación de la que no puede rehuir quien vive, así como definitivamente establece en su famosa fórmula que sigue poco después de las anteriormente citadas: «yo soy yo y mi circunstancia y si no la salvo a ella no me salvo yo» ${ }^{11}$.

\section{CONCEPTUALISMO Y ARTE IMPOPULAR}

El arte al que nos han acostumbrado los últimos siglos, sea neoclásico, romántico o realista, indica Ortega, es arte "popular», porque entre el mundo del espectador y el de la obra se facilita una transmigración espontánea. El «arte antiguo» dilata, prolonga o problematiza la vida en una obra que a simple vista puede contemplarse y admirarse, porque se interesa en nuestro destino y nos hace parte de ella. El cristal que se interpone entre lo real y lo artístico si no es transparente es por lo menos translucido, el enfoque posible, el pacto de ficción

mundo o circunstancia en que me encuentro sumido no es sólo el paisaje que me rodea, sino también mi cuerpo y también mi alma». O.C. V, p. 571). Pero, además, lejos de establecerse aquí la verdad como una adecuación del pensamiento a la cosa, se declara la adecuación de la circunstancia al proyecto, y, a la vez, del proyecto que surge circunstancialmente, es decir, según una razón histórica circunstancial, inevitablemente biográfica. La mano se mueve ya adaptada al medio, pero todo movimiento suyo implica forzar el medio a funcionar para llevar a cabo su tarea, intrínsecamente falible. En este sentido, el órgano ya es función, la circunstancia ya es proyectiva, no hay distancia entre ambos sino "dualidad unitaria» en el movimiento de la vida. Como se ha repetido, y sobre todo ha mostrado magistralmente J. Marías, es a partir de los conceptos de Umwelt und Innerwelt der Tiere (1909) de la obra de von Uexküll y, aún más, Bausteine zu einer biologischen Weltanschauung (1913), según declara el mismo Ortega en el prólogo a la versión española de este texto, de 1922, que va perfilándose la radicalidad del concepto de circunstancia, que va incluyendo ya en las Meditaciones del Quiote «los espacios exteriores» y los «insensibles» - mi cuerpo, mi psique, la historia entera..., en definitiva, «el mundo» como todo lo que puedo encontrarme para encontrarme proyectiva o ejecutivamente (Cf. Tomo I, p. 780). Para más detalles cf. MARías, J., en su comentario a las Meditaciones del Quijote, Cátedra, Madrid, 2010, nota 32, y, más aún, del mismo autor: Ortega. circunstancia y vocación, Obras, IX, Revista de Occidente, Madrid, 1982, apartados 65, 68.

10 O.C. I, p. 756.

$11 \quad$ Ibid. p. 757. 
de inmediato consentido. ¿En qué consiste la ruptura del arte figurativo con el adviento de las vanguardias que desde la pintura se han ido extendiendo a todos los demás géneros artísticos? Se la ha definido como "abstracción». Étienne Gilson, sin embargo, ha advertido que con esta expresión no hay que referirse a lo no representativo. Un cuadro puede ser figurativo pero de ningún modo imitativo en la medida en que remiten sus formas a lo invisible por excelencia, a la interioridad del pintor. Esta remisión a las profundidades íntimas del artista es lo que transfigura una obra en términos de abstracción, y es lo que lleva a argumentar agudamente a Jean Bezain —en quien Gilson se inspira para esta distinción - que Kandinsky es menos abstracto que Brueghel, Vermeer o Van Eyck. No es la imitación ni ningún tema poético aquello que podría establecer un canon de belleza o una experiencia del gusto que define lo artístico de una obra. Así se ocultaría la raíz última de la visibilidad del arte: la pura plasticidad como libertad de la forma. Esa raíz, indica Gilson, se encuentra remotamente descubierta en Delacroix, desde el cual se puede tender un hilo conductor hasta su máxima expresión en Piet Mondrian. Es el pintor neerlandés quien libera definitivamente lo figurativo del arte de temáticas e ideologías, remontando la plasticidad al mundo del artista, en vista del cual ninguna forma, en principio, es exenta de "sacrificio», porque la abstracción de la obra no es otra cosa que la expresión de la libertad creativa ${ }^{12}$. Esta intuición de Gilson acerca de la esencia del arte vinculada al destino plástico que adquiere la forma en la intimidad artística ofrece un primer acercamiento al concepto de estilo de Ortega, si bien la función filosófica y su inspiración metafísica, como veremos, varían sensiblemente respecto del molde tomista del pensador francés.

La vanguardia artística, según Ortega, tiene un tema poético complejo, nada desdeñable intelectualmente, que la hace por lo pronto impopular, porque supone una ruptura incomprensible y perturbadora entre lo cotidiano y lo ficticio. Por supuesto, la ruptura es intrínseca a todo arte; es consustancial al pacto de ficción en cuyo tránsito se descifra el peculiar goce estético del espectador, que se proyecta a otro mundo aceptando que se le niegue el propio ${ }^{13}$. Y la existencia misma de ruptura y pacto refleja la inseparabilidad entre la estética como teoría y la expresión de un arte concreto $^{14}$, que obliga a todo gesto artístico creador a resumir y justificar la tradición, revelando de nuevo sus temas, es decir, originándolos desde un nuevo estilo.

¿En qué consiste entonces la ruptura y el pacto del arte de vanguardia, su esencial tema poético, el temple lírico en que pretende instalarse y la exploración de su técnica?

12 Cf. Gilson, E., Painting and reality, Pantheon Books, New York, 1959, p. 234ss.

13 Incluso respecto de otro arte, el de la caza, sostendrá Ortega que su goce depende de sustraer al hombre de su cotidianidad introduciéndole en el «mundo» animal. Y el entretenimiento en este mundo consiste, literalmente, en «unas vacaciones de humanidad». Cf. Prólogo a Veinte años de caza mayor, del conde de Yebes, O.C. VI, p. 320.

14 Cf. esta idea desde Adán en el Paraíso: «la estética vale tanto como la obra de arte». O.C. II, p.62. 
«El arte viejo» perturba y rapta de la cotidianidad en la medida en que busca otro mundo en que humanizarla, pues supone tácitamente que la misión del arte es transcendente, tanto respecto de la elección de sus temas, tan grávidos de ideales humanos, como de las situaciones concretas que pretende dignificar. El romanticismo no ha sido ajeno a esa creencia antigua, exponiéndola con sus estilos y temas; sin embargo, en la equilibrada quietud del realismo de finales del XIX, que prescinde de la fantasiosa ironía romántica, de su monumental contraste entre naturaleza y hombre, se presagia la tormenta. La vanguardia llega a rechazar formas que reproducen enalteciendo, así como cualquier lirismo de exaltación de la problemática normalidad de la cotidianidad humana acompañada de técnicas que buscan armonizarla. El arte de vanguardia quiere ser solo arte, fin a sí mismo, y para ello entiende que su misión es desrealizar todo ideal de realidad, deshumanizar el mundo y, si acaso, introducir al hombre solo indirectamente. No como referencia figurativa, centro representativo beatífico y originario de la forma, sino como producto de la voluntad de estilo del artista. No conclúyase, sin embargo, que el arte nuevo odia al antiguo; se burla jovialmente de él, de sus ideales, de sus estilos, de su ridícula seriedad que presume que el arte sea también sociología, ética, psicología, política o religión. Desvinculada de estos altos ideales, la vanguardia proclama la ficción en sí, pero no tanto —como nos desveló el mimo- porque sugiere la importancia del arte como conciencia cultural del hombre, sino, más bien, porque la ficción en este caso es burla de sí, y, finalmente, en el burlarse de la burla encuentra la creatividad lúdica de su estilo, que al esteta clásico le parece una insoportable farsa. Mas, afirma Ortega, "Sería "farsa" — en el mal sentido de la palabra - si el artista actual pretendiese competir con el arte "serio" del pasado y un cuadro cubista solicitase el mismo tipo de admiración patética, casi religiosa, que una estatua de Miguel Ángel. Pero el artista de ahora nos invita a que contemplemos un arte que es una broma, que es, esencialmente, la burla de sí mismo. Porque en esto radica la comicidad de esta inspiración. En vez de reírse de alguien o algo determinado — sin víctima no hay comedia-, el arte nuevo ridiculiza el arte ${ }^{15}$. Y termina advirtiendo: «Todo el arte nuevo resulta comprensible y adquiere cierta dosis de grandeza cuando se le interpreta como un ensayo de crear puerilidad en un mundo viejo» ${ }^{16}$.

¿Deberíamos entonces concluir que la vanguardia principalmente consiste en un contra-estilo, que su lirismo es una sarcástica evaporación del arte que le precede y que su tema poético, siendo una mera exaltación de la creatividad complacida de sí, convierte su técnica, eliminada la pericia representativa, en un mero accesorio lúdico que hace artista a cualquier diletante? No es este el juicio de Ortega —ni de quien le acompaña con estas líneas-, por lo menos respecto de los comienzos de las vanguardias en su preciso sentido histórico.

Se ha subrayado, como caracteres del arte contemporáneo, la espontaneidad en la experiencia de la forma y el color: su descomposición en impresiones

15 O.C. III, p. 873.

16 Ibid. p. 875. 
fugaces que se imponen al sujeto, o su derivación expresiva de una intimidad insondable; también, la exploración de las dimensiones periféricas de la vida (sueño, inconsciencia, enajenación mental o social...); o la narración de la asombrosa aceleración técnica en contraste con las necesidades de las tradiciones ancestrales... ¿No serán todos ellos objetivos poéticos que desembocan en un arte que acepta todas sus variaciones abstractas porque, en el fondo, es esencialmente conceptual, como definitivamente revelan los conceptualismos de las últimas vanguardias, que finalmente declaran que es el artista quien prepara la experiencia contemplativa del espectador concibiendo a priori lo que es artístico de una obra, incluyendo en ella el espacio y el contexto de su exposición? ${ }^{17}$. Sin duda, habría que analizar con cautela los nuevos atributos de los que se ha hecho portadora la obra de arte contemporánea, así como el horizonte de posibilidades que sugiere al artista y a las que el público se ha ido acostumbrando en las exposiciones, interpretadas, cada vez más, como «instalaciones», «performance», etc. Sin embargo, antes de eso, tendremos que medir con más precaución aún en qué consiste la misma posibilidad del arte conceptual, y si es este, efectivamente, el atributo que aclara la índole de la vanguardia.

El realismo, vuelve a recordar Ortega en la Deshumanización del arte, consiste en la nativa propensión humana a creer que las cosas son lo que pensamos de ellas, cometiendo una «ingenua idealización de lo real» ${ }^{18}$. Podríamos pensar que el arte nuevo, rebelándose frente a lo que percibe como una cándida beatería, dispone abstraerse de toda creencia realista y aboga por defender una neutralidad descriptiva, creativamente escéptica, ante el mundo y sus formas. Sin embargo, como hemos anticipado, el propósito del arte nuevo es polémico, contradictorio, nada descriptivo, pues incluso en la descripción vería la misma hipocresía del representacionismo que se cree en franquía de ideales interpretativos. Lo que pretende, al contrario, es oponerse al realismo: realizar adrede las ideas en vez de idealizar ingenuamente lo real. «Si ahora, en vez de dejarnos ir en esta dirección del propósito, lo invertimos y, volviéndonos de espaldas a la presunta realidad, tomamos las ideas según son

17 J.-L. MARION, por su parte, en La croisée du visible entiende por arte conceptual, más bien, una tendencia que puede adherirse a estilos artísticos de cualquier época, que consiste en privilegiar «la idea» sobre "el ojo» —como dirá también en su estudio sobre Courbet—, con la consecuencia de prever y acotar conceptualmente la visión hasta contravenir a la misión del arte: manifestar lo invisto - lo que todavía no es visible- en lo visto. En Étant donné. Essai d'une phénoménologie de la donation (Presses Universitaires de France, Paris, 1997) el cuadro se estudia como fenómeno saturado según la cualidad (ídolo), de ahí que satura la intuición, desborda el concepto, convoca el ojo a continua admiración, a diferencia de los productos técnicos (objetos de derecho común) que pretenden acotarla. ¿Es realmente el concepto lo que es desbordado por la obra de arte? La respuesta de Ortega, como anticipa el título del presente apartado, se gesta a nivel ejecutivo y metafórico, pues intuir ya es significar; no se pueden separar estas dos dimensiones en la perspectiva; percepto ya es escorzo y, por tanto, concepto, como veremos.

18 O.C. III, p. 867. 
-meros esquemas subjetivos- y las hacemos vivir como tales, con su perfil anguloso, enteco, pero transparente y puro - en suma, si nos proponemos deliberadamente realizar las ideas-, habremos deshumanizado, desrealizado éstas. Porque ellas son, en efecto, irrealidad. Tomarlas como realidad es idealizar - falsificar ingenuamente. Hacerlas vivir en su irrealidad misma es, digámoslo así, realizar lo irreal en cuanto irreal. Aquí no vamos de la mente al mundo, sino al revés, damos plasticidad, objetivamos, mundificamos los esquemas, lo interno y subjetivo. [...] El cuadro, renunciando a emular la realidad, se convertiría en lo que auténticamente es: un cuadro - una irrealidad. El expresionismo, el cubismo, etcétera, han sido en varias medidas, intentos de verificar esta resolución en la dirección radical del arte. De pintar las cosas se ha pasado a pintar las ideas: el artista se ha cegado para el mundo exterior y ha vuelto la pupila hacia los paisajes internos y subjetivos» ${ }^{19}$. El arte nuevo, acaba afirmando Ortega con una referencia a Pirandello, no se limita a un drama de personajes cuyas ideas y destinos articulan la representación teatral, sino concibe el teatro como representación de ideas en sí, un drama de ideas que prescinde de los personajes y funda el goce estético en la fuga de lo figurativo, en la ironía de lo desfigurado, en la fantasía deshumanizadora.

¿No deberíamos avenirnos a la definición conceptualista de las vanguardias? $¿$ ¿No es ese drama de ideas, por encima de cualquier otro objetivo, el tema poético del arte nuevo, cuyo refinamiento técnico solo sirve a la creatividad en sí?

Si el idealismo, en el fondo, es la explicitación del realismo, variando el acento metafísico de lo que cada uno cree realizar -ingenuamente la idea en la cosa o la cosa en la idea-, queda por esclarecer la razón de la necesidad por la cual la vida misma, como nos anticipó el mimo, es de por sí, por debajo de todo pensamiento y como condición suya de posibilidad, un pacto de ficción que implica un compromiso de realización que se expresa en el movimiento primigenio que es el cuerpo humano, razón última de la técnica. En otras palabras, si la vida es el arte supremo que entraña la posibilidad de la ficción, habrá que preguntarse: ¿cuál es el tema poético que forja su pacto, la razón biográfica de la carne que lo realiza y cuyo drama postula una continua búsqueda de lirismo que, entonces, sería el alimento creativo de cualquier expresión artística concreta?

\section{LA RAZÓN HISTÓRICA DEL ARTE NUEVO Y LA LÓGICA METAFÓRICA DE LA EJECUTIVIDAD}

En la Deshumanización del arte, en un revelador apartado titulado «Unas gotas de fenomenología», Ortega reivindica, frente a quien sustantiva la postura reflexiva y la adopta acríticamente como punto de partida, la primacía de la vida ejecutiva que justifica toda reflexión, porque esta es siempre a su vez

$19 \quad$ Ibid. p. 868. 
ejecutiva, al igual que el gesto artístico, como dijimos, implica inevitablemente una teoría estética ${ }^{20}$.

Es diferente la distancia espiritual y por tanto el punto de vista objetivante que puede tener un médico a la hora de examinar los últimos estertores de un hombre enfermo, respecto de la de un periodista o de un pintor, eventualmente interesados en relatar una historia u observar la estética de la muerte. Todos estos estilos contemplativos parecen construir puntos de vista que comprenden la situación parcialmente, abstrayéndose del drama concreto del moribundo. Si se considera como último personaje de la escena a la mujer del enfermo, al contrario, es evidente que su contemplación es narrativamente inseparable de la experiencia plena del dolor del marido; en ella es evidente que lo vivido es también lo contemplado. En un extremo, dice Ortega, tenemos la realidad «vivida» de la esposa sufriente, en el otro, la realidad «contemplada» de la ciencia y del arte. A partir de estos dos puntos de vista es necesario «hacer una advertencia esencial para la estética, sin la cual no es fácil penetrar en la fisiología del arte, lo mismo viejo que nuevo. Entre esos diversos aspectos de la realidad que corresponden a los varios puntos de vista, hay uno de que derivan todos los demás y en todos los demás va supuesto. Es el de la realidad vivida. Si no hubiese alguien que viviese en pura entrega y frenesí la agonía de un hombre, el médico no se preocuparía por ella, los lectores no entenderían los gestos patéticos del periodista que describe el suceso y el cuadro en que el pintor representa un hombre en el lecho rodeado de figuras dolientes nos sería ininteligible. Lo mismo podríamos decir de cualquier otro objeto, sea persona o cosa. La forma primigenia de una manzana es la que ésta posee cuando nos disponemos a comérnosla. [...] Quiere decir esto que en la escala de las realidades corresponde a la realidad vivida una peculiar primacía que nos obliga a considerarla como «la» realidad por excelencia. En vez de realidad vivida, podíamos decir realidad humana. El pintor que presencia impasible la escena de agonía parece «inhumano». Digamos, pues, que el punto de vista humano es aquél en que «vivimos» las situaciones, las personas, las cosas. Y, viceversa, son humanas todas las realidades - mujer, paisaje, peripeciacuando ofrecen el aspecto bajo el cual suelen ser vividas ${ }^{21}$. Las consecuencias no pueden ser más claras y graves, y no hacen que reflejar un estado teórico que Ortega ha abordado desde 1914, si bien hay que remontarse por lo menos a 1910, como veremos, para encontrar su raíz.

20 La imposibilidad de prescindir de prejuicios, de alcanzar una ciencia sin supuestos, así como predicaba Husserl en esas fechas, ha sido rotundamente rechazada por Ortega a lo largo de toda su obra. Bástese ver, desde sus primeros ensayos, el inicio de Adán en el paraíso, las reiteradas reflexiones en las Meditaciones del Quijote sobre la cultura ("vuelta táctica que hemos de tomar para convertirnos a lo inmediato» O.C. I, p. 756) y la historia («la muerte de lo muerto es la vida. Sólo un modo hay de dominar el pasado, reino de las cosas fenecidas: abrir nuestras venas e inyectar de su sangre en las venas vacías de los muertos.» Ibid. p. 759), y la crítica literaria a la que ya me he referido; sin contar con la misma idea de perspectiva, que en Ortega no es otra cosa que la proyección circunstancial de la vida, el irrepetible hacerse de su profundidad biográfica, histórica.

21 O.C. III, p. 856. 
Realismo, idealismo, o cualquier «gota» de puro afán descriptivista fenomenológico se diluyen en el curso inapresable de la vida individual, en la narración ejecutiva que es la «realidad vivida» — «la realidad radical», dirá Ortega—a partir de la cual se hace inteligible cualquier acto reflexivo, es decir, cultural. La famosa y fundamental crítica orteguiana a la fenomenología ya está aquí preparada argumentalmente, pues es inevitable desde estos supuestos teóricos, así como explica Ortega en el Prólogo para Alemanes - a El tema de nuestro tiempo-en que detalla con precisión el nacimiento de su propio pensamiento ${ }^{22}$. La abstracción plástica —en el sentido de Bezain y Gilson - reconduce a la intimidad del sujeto que estiliza la obra, es decir, inevitablemente desrealiza porque realiza desde su irrenunciable perspectiva: su misma vida. Y esta, irreductible a cualquier abstracción o estilo - porque es fuente de todo estilo- no surge de un pacto del pensamiento, no se establece mediante un acto de conciencia, es decir, desde «el yo» del pintor, del médico, del periodista, del científico, del fenomenólogo. Mi vida no es «el yo», "un acto» o una «conciencia de», sino «yo», esto es, pacto que compromete a realizar la vida fáctica o dramáticamente, es decir, circunstancialmente. En definitiva, es a partir de «la realidad vivida», que es «el punto de vista humano», que puede comprenderse cualquier otro pacto que pretende realizarla según temas poéticos derivados -incluso deshumanizadores, como en el arte de vanguardia-. Cada yo, como realidad ejecutándose, por tanto, es la razón plástica de todo cuerpo, de la circunstancia, que siempre es mía porque se da proyectada: estilizada desde mi vida, así como el dolor del moribundo se estiliza desde cada vida que lo contempla.

Once años antes, en su Ensayo de estética a manera de prólogo (1914), Ortega ya había abordado esta cuestión teórica, reveladora del punto de arranque

22 Téngase en cuenta toda esta obra, que trata en detalle esta cuestión; considérese aquí este extracto: «La respuesta no ofrece duda: esa conciencia pura, esa pura vivencia, tiene que ser obtenida mediante una "manipulación" del filósofo que se llama "reducción fenomenológica". Ya esto es grave, tan grave como lo que ha acontecido al físico cuando ha querido observar el interior del átomo: que al observarlo entra él en el átomo, interviene y lo modifica. En vez de hallar una realidad, la fabrica. Así el fenomenólogo. Lo que éste de verdad encuentra es la "conciencia primaria", "irreflexa", "ingenua", en que el hombre cree lo que piensa, quiere efectivamente y siente un dolor de muelas que duele sin otra reducción posible que la aspirina o la extracción. Lo esencial, pues, de esa "conciencia primaria" es que para ella nada es sólo objeto, sino que todo es realidad. En ella el darse cuenta no tiene un carácter contemplativo, sino que es encontrarse con las cosas mismas, con el mundo. Ahora bien, mientras ese acto de "conciencia primaria" se está ejecutando no se da cuenta de sí mismo, no existe para sí. Esto significa que esa "conciencia primaria” no es, en rigor, conciencia. Este concepto es una denominación falsa de lo que hay cuando yo vivo primariamente, es decir, sin ulterior reflexión». "La "reflexión" — repito- es una situación real tan ingenua como la "primaria" y como ella irreflexa con respecto a sí misma.» (Tomo VIII, p. 156-157), Por tanto, «esa realidad radical que es la vida propia no consiste en "conciencia", en Bewußtsein, sino en una radical dualidad unitaria, como el Ginkgo biloba de Goethe que es uno-dos. Nuestra vida, la de cada cual, es el diálogo dinámico entre "yo y sus circunstancias"». (Ibid. p. 151). Mi vida, termina diciendo Ortega, es «el acontecimiento absoluto», «la absoluta realidad». 
del método de la razón vital. Ni una cosa, como un libro, ni una ocupación, como la de un poeta, puede abstraerse de la vida concreta de la persona, de su estilo propio. «El valor característico de este libro [El Pasajero de Moreno Villa, al que se dedica el prólogo] consiste, según he dicho, en anunciar un poeta verdaderamente nuevo, un estilo, una musa» ${ }^{23}$. Con la interpretación del acto artístico se va revelando la estructura de la vida humana: el estilo procede de la individualidad, pero se verifica en las cosas. "La peculiar manera que en cada poeta hay de desrealizar las cosas es el estilo. Y como, mirado por la otra cara, la desrealización no se logra si no es por una supeditación de la parte que en la imagen mira al objeto a la parte que ella tiene de subjetiva, de sentimental, de porciúncula de un yo - se comprende que haya podido decirse: el estilo es el hombre.

Pero no se olvide que esa subjetividad sólo existe en tanto que se ocupa con cosas, que sólo en las deformaciones introducidas en la realidad aparece. Más claro: el estilo procede de la individualidad del "yo", pero se verifica en las cosas $»^{24}$.

Frente al realismo o al idealismo, que creen en el ser como función de realidad que realiza las ideas en las cosas o las cosas en las ideas, todo cuanto hay, previo al pensamiento, a su objetivación o entificación, se da como algo en tanto y en cuanto ejecutándose según estilo, es decir, como «yo». «Hacer de algo un yo mismo es el único medio para que deje de ser cosas», a saber, cosa en sí, ente u objeto mentado por un acto de conciencia. «Yo significa, pues, no este hombre a diferencia del otro, ni mucho menos el hombre a diferencia de las cosas, sino todo - hombres, cosas, situaciones-, en cuanto verificándose, siendo, ejecutándose. Esta caja de piel roja que tengo delante de mí no es yo porque es sólo una imagen mía, y ser imagen equivale justamente a no ser lo imaginado. Imagen, concepto, etcétera, son siempre imagen, concepto de... y eso de quien son imagen constituye el verdadero ser. La misma diferencia que hay entre un dolor de que se me habla y un dolor que yo siento hay entre el rojo visto por mí y el estar siendo roja esta piel de la caja. Para ella el ser roja es como para mí el dolerme. Como hay un yo Fulano de Tal, hay un yorojo, un yo-agua y un yo-estrella. Todo, mirado desde dentro de sí mismo, es yo. Ahora vemos por qué no podemos situarnos en postura utilitaria ante el "yo": simplemente porque no podemos situarnos ante él, porque es indisoluble el estado de perfecta compenetración con algo, porque es todo en cuanto intimidad» ${ }^{25}$.

\section{O.C. I, p. 654.}

$24 \quad$ Ibid. p. 658.

25 O.C. I, p. 668. Reténgase el gerundio «siendo», solo aquí utilizado en dos ocasiones para aclarar la visión ejecutiva o real de la realidad. La ejecutividad de la circunstancia es lo que la hace ser, es decir, siendo. Se repite esta idea a lo largo de toda la obra de Ortega para criticar la interpretación ontológica de la vida, esto es, como conciencia o identidad del pensamiento consigo mismo. No es infrecuente encontrar escritos donde se llega a identificar la ejecutividad de la que habla Ortega con la intencionalidad de Husserl, sosteniendo, con ello, 
Así como en la Deshumanización del arte la muerte del esposo cobraba realidad solo desde «el punto de vista humano» de "la realidad vivida», simbolizada por la esposa que participaba sin posibilidad de poner entre paréntesis contemplativamente su dolor, revelando cada uno de los demás puntos de vista como estilos derivados de sendas vidas concretas; y así como la forma primigenia de la manzana es la que posee cuando nos disponemos a comérnosla..., en esta obra de 1914 ya se había proporcionado el sustrato teórico que acompaña toda la doctrina de Ortega: que cualquier realidad, en cuanto real - es decir, no como objeto o ente-, se da ejecutivamente en ese movimiento dramático, originariamente artístico o técnico que es mi vida. Las cosas «en sí» son una abstracción cuya ficción de realidad o idea es el ser como instrumento del pensamiento para adecuarse a ellas y prescindir de su continua variabilidad; sin embargo, como acabamos de ver, cuando hablo de «cosas», me refiero a «todo - hombres, cosas, situaciones-, en cuanto verificándose, siendo, ejecutándose», porque «yo» es «estado de perfecta compenetración con algo, porque es todo en cuanto intimidad». "Yo», por tanto, es razón de plasticidad, fuente de estructuración, en definitiva - dirá Ortega- «mi vida» como perspectiva o proyecto circunstancial. En vez de «el yo» como «conciencia», plena adecuación del pensamiento consigo mismo, «yo» como «mi vida» «soy yo y mi circunstancia», proyecto circunstancial. De ahí que la circunstancia es mía porque se da proyectivamente, ejecutándose, en perspectiva, en «perfecta compenetración con mi intimidad», estilizándose ${ }^{26}$.

Pero la tentación de sustantivar una postura reflexiva y desvincularla de su razón ejecutiva se da también respecto de mi yo, que puede confundirse con ese yo recordado, imaginado, convertido, por ejemplo, en polo de acción

que la epistemología de Ortega es descriptiva, representacionista, en vista de la captación de la idealidad. Ello haría — por lo menos para mí- que su pensamiento no tuviera interés filosófico, ya que se ocultaría precisamente la raíz de su originalidad: la razón ejecutiva, narrativa, histórica, creadora de la vida. Cf., entre los que fenomenologizan a Ortega o llegan a sostener su descriptivismo, Cerezo Galán, P., La voluntad de Aventura. Aproximación crítica al pensamiento de Ortega y Gasset, Ariel, Barcelona, 1984, p. 250-252; o, con más atención a la estética de las primeras obras de Ortega, Ph. SiLVER, "La estética de Ortega», NRFH, vol. 22, n. 2, 1973, p. 299.

26 "Yo» como «mi vida», para que se sitúe históricamente el precoz descubrimiento de Ortega, es inadecuación, «diacronía» como condición —o, mejor dicho, razón- de posibilidad de toda «sincronía», si quisiéramos utilizar la terminología del último Levinas. En la diacronía, como puro decir que se revela en el rostro, se posibilita todo signo como «dicho», y que, aún así, entraña una traza de ese decir convirtiéndose en ella para significar en la verdad. Cf. Autrement qu'être au-delà de l'essence. La cuestión que queda abierta es la razón de esa ejecutividad, que evidentemente no corresponde a cómo se ha producido la infinitud diacrónica de Levinas (mediante la Illeité, principio que me ha elegido a una tarea que me transciende y al que no puedo remontarme en este presente que, por tanto, anárquico y anacrónico, ya está pasado de sí, y que siempre me pasará en un futuro que irá revelando esa tarea en el rostro del prójimo: no matarás). Menos aún, tiene algo que ver con la vida prereflexiva de la conciencia husserliana, como habrá ocasión de comentar. 
y pasión intencional, o mero receptáculo yóico de retención y protención temporal para la manifestación últimamente sensible del ser de las cosas. Sin embargo, así se separarían las cosas de su ejecutividad, la circunstancia de su proyecto, y se limitaría el concepto de «perspectiva» a un espectáculo de la actitud mundana de la conciencia sobre el que la reflexión ejerce una síntesis de identificación y acota, mediante la «x» inadecuada pero apodíctica de cada objeto, regiones ontológicas como modos de ser ideales y relativos a la región radical de la conciencia intencional. Así se confundiría la intencionalidad del ego transcendental con la proyectividad circunstancial de la vida humana, que es, ella misma, en cuanto realidad radical, perspectiva, «todo ejecutándose ${ }^{27}$. Mi vida, entonces, tampoco puede oponerse o asimilarse a la interioridad cinestésica o a los espacios exteriores, sino que es todos ellos en tanto y en cuanto ejecutándose. "Sólo con una cosa tenemos una relación íntima: esta cosa es nuestro individuo, nuestra vida, pero esta intimidad nuestra al convertirse en imagen deja de ser intimidad. Cuando decía que en el "yo ando" nos referíamos a un andar que fuera visto por su interior, aludía a una relativa interioridad; con respecto a la imagen del moverse un cuerpo en el espacio es la imagen del movimiento de mis sensaciones y sentimientos como una interioridad. Pero la verdadera intimidad que es algo en cuanto ejecutándose, está a igual distancia de la imagen de lo externo como de lo interno $^{28}$. La intimidad no puede ser objeto nuestro ni de la ciencia, ni en el pensar práctico, ni en el representar maquinativo. Y, sin embargo, es el verdadero ser de cada cosa, lo único suficiente y de quien la contemplación nos satisfaría con plenitud $»^{29}$.

Yo, en cuanto "intimidad», "nuestra vida», no puede ser objeto de ciencia —aunque sea strenge Wissenschaft_, ni de pensar práctico o de un representar maquinativo, pues es la perspectiva —evidentemente filosófica-irreductible a puntos de vista reflexivos que la interpretan, siendo ella misma el supuesto ejecutivo de toda reflexión, es decir, la razón de la ejecutividad, de que vida sea quehacer —según terminología más «madura». El rojo, el agua, la estrella o Fulano, ya nos ha dicho Ortega, no son seres reales o ideales, sino yo-rojo, yoagua, yo-estrella, yo-Fulano, esto es, realidades ejecutivas o proyectivas, cuya plasticidad se da en mi vida que inevitablemente desrealiza porque siempre realiza en perspectiva, estiliza. Todas las cosas, incluso mi cuerpo entre ellas, soy «yo, verdadera intimidad que es algo en cuanto ejecutándose», por tanto,

27 «¿Cuándo nos abriremos a la convicción de que el ser definitivo del mundo no es materia ni es alma, no es cosa alguna determinada, sino una perspectiva?». O.C. I, p. 756.

${ }_{28}$ Compárese con este texto al que ya se ha aludido, de las Meditaciones del Quijote: «iEl mundo exterior! Pero ¿es que los mundos insensibles - las tierras profundas- no son también exteriores al sujeto? Sin duda alguna: son exteriores y aun en grado eminente». Si no se admite la exterioridad tanto de la psique como del cuerpo, corremos el peligro de que se «nos desaloje de nosotros mismos, vacíe nuestra intimidad, y exentos de ella quedemos transformados en postigos de camino real por donde va y viene el tropel de las cosas». Ibid. p. 780.

29 Ibid. p. 670. 
fuente última de su movimiento, es decir, de técnica, de arte. Y si el cuerpo es también circunstancia, significa que esta es, a su vez, ejecutivamente corpórea, inevitablemente carnal, y mi vida perspectiva de encarnación de todo cuerpo. El hecho de que para Ortega el cuerpo sea también circunstancia, y que esta sea, por tanto, «mía» como es mío aquel, tiene dos consecuencias decisivas: en primer lugar, aborda con precisión lo que Merleau-Ponty con frase acertada llamará «carne del mundo» ${ }^{30}$,y, más aún, establece que solo la razón del cuerpo humano, de su espacialización como movimiento ejecutivo, puede dar razón de cualquier otro cuerpo, es decir, de la circunstancia ${ }^{31}$. En efecto, sería contravenir a la raíz ejecutiva de la circunstancia interpretar a esta como materia de la física, de la química o de la biología. Interpretada filosóficamente, es decir, ejecutivamente, la circunstancia está hecha de vida, de intimidad, pues "yo» es la raíz del movimiento, es «todo — hombres, cosas, situaciones—, en cuanto verificándose, siendo, ejecutándose». En segundo lugar, más allá de MerleauPonty, y de concierto con Levinas, si del sentido de la ejecutividad — de la razón del proyecto- deriva la transcendencia, también de aquel debería depender el sentido ético de esta en cuanto circunstancialidad de la vida.

30 Cf. Merleau-Ponty, M., Le visible et l'invisible, Gallimard, 1964. Mi cuerpo, como sintiente y sentido (fenoménico y objetivo, según la terminología de la Phénoménologie de la perception), es la profundidad de las cosas del mundo, «haciéndome yo mundo, y haciendo a estas carne» (p. 176), de ahí que la carne, como intersección entre la visión y lo visible, entre mundo y cuerpo, es elemento del ser del que surge fácticamente el dónde y el cuándo (p. 182). Para Merleau-Ponty el vidente se une a lo visto —el mundo- incorporándose a lo visible. Esta unión entre el vidente y lo visto como condición de lo visible es la carne, que es lo transcendente, pues soy propiamente yo y más que yo: condición de todo cuerpo. Es, la carne, llega a decir reveladoramente Merleau-Ponty, como el elemento de los presocráticos; como el agua de Tales que me constituye y a la vez constituye el mundo. Sin embargo, en esta apercepción carnal del mundo en que consiste mi cuerpo personal, no estamos hablando de un cuerpo y por tanto de una apercepción biográfica, de una carne como cuerpo falible, técnico, que se hace en un presente inseguro porque dramático. En definitiva, se trata de la encarnación de la conciencia intencional husserliana, sin razón proyectiva personal o razón ética de alteración del Mismo que justifique un cuerpo personal (Levinas).

31 Se entiende ahora con más precisión lo afirmado anteriormente: que la estructura universal de la temporalización de la conciencia como retensión y protensión impide comprender la proyección circunstancial de mi vida, pues separa proyecto y circunstancia. En efecto, Retensión-Protoimpresión-Protensión, además de suponer ya el tiempo (que queda indefinido en su mismo surgir o punto fuente -Urpunkt-) escinde lo yóico —esa misma estructura- de la razón eidética de la asociación, que de ser yóica o no serlo, acabaría en todo caso hacia la aporía realismo-idealismo. Esta, inevitablemente, es traída por el sentido adecuacionista de la intencionalidad activa, que intenta prolongarse en la estructura pasiva de la autoconciencia. Un camino más fecundo toma D. Franck en su Chair et corps (Les éditions de Minuit, Paris, 1981), intentando prescindir de ese esquema yóico temporalizador, centrándose en la reducción al yo propio de las Meditaciones cartesianas de Husserl. Dicha reducción, sostiene agudamente, es imposible, pues el cuerpo propio ya implica a otros cuerpos. Así tiene que admitir finalmente Franck — sin saber muy bien qué hacer con ello desde el método fenomenológico genético- que preguntarse por la génesis del cuerpo es lo mismo que preguntarse por la génesis del mundo, porque la experiencia de lo propio conduce a lo propio de la experiencia, a la carne ya intersubjetiva (p. 92ss). 
Ahora bien, hemos repetido que se puede hablar de cosas, situaciones, personas desde el pensamiento, objetivándolas, pero yo, mi vida, soy proyecto circunstancial, lo que significa también carnal, en el sentido de un cuerpo biográfico que remite a un estilo propio como razón última de toda plasticidad. Esto significa que tanto para mi vida, como para cualquier proyecto artístico concreto, la plasticidad de las formas no está exenta de un temple sentimental. Más aún, sostiene Ortega que el sentimiento es el mismo estado ejecutivo de lo figurativo, de ahí que cuando una imagen se transpone con otra, es decir, varía la estructura en que suele perfilarse, cambia también su lugar sentimental. Si decimos "ciprés», es inevitable una reacción subjetiva en que vibra nuestro ambiente sentimental. Esta reacción, llega a decir Ortega, "no es sino el acto de percepción, sea visión, recuerdo, intelección, etc.»; y, forzosamente concluye, no nos damos cuenta de ella porque «nuestra intimidad no puede ser objeto para nosotros» ${ }^{32}$. Si ahora emparejamos la imagen ciprés con la de un objeto que normalmente no convive sentimentalmente con ella, una «llama», así como nos invita a hacer el poeta López Pico, y se nos fuerza a ver el ciprés como llama ${ }^{33}$, entonces se produce una transposición sentimental -y por tanto perceptiva - que es propiamente la creación de un tercer objeto, el ciprés-llama, irreductible a los dos anteriores, y que se forja resaltando la similitud en la diferencia (respectivamente, por ejemplo, la forma de llama con la de ciprés, el fresco verdor vegetal con el ardor reluciente del fuego...). La lógica de creación del nuevo objeto no es "asimilación» o "aproximación de semejanzas», sino la de un decir que es percibir una cosa con otra, de ahí que los conceptos de ambas se ven ejecutivamente arrastrados en otra ulterior, una tercera, que ha transpuesto el lugar sentimental de aquellas y nos las hace ver desde otra dimensión antes impensable: la belleza. La metáfora, porque de esto se trata, ha desrealizado ejecutivamente la realidad —en el sentido de lo habitualmente realizado o perfilado- a través de un estilo poético que se va haciendo al compás de la vida misma, pues actúa desde su ejecutividad, desde el origen de su perspectiva.

La metáfora implica inevitablemente un pacto de ficción en cuanto realización poética de un nuevo objeto, de ahí que revela que lo real, lo verdaderamente ejecutivo, siempre es lo realizado en cuanto creado. En definitiva, desvela que ejecutivamente la realidad es transposición fecunda, creación que estructura nuevos lugares sentimentales que dilatan el mundo y que, en la medida en que eran impensables, nos sugieren equivocadamente que el arte es sentimiento sin concepto (Kant), cuando, en rigor, desde la razón ejecutiva de la vida, desde la lógica metafórica de la perspectiva como carne, sentir ya es percibir, esto es, realizar originariamente un estilo.

32 O.C. I, p. 76

33 En realidad, el ciprés sería como «el espectro de una llama muerta», pero al igual que Ortega, retenemos solo una metáfora de las dos que entraña la frase, simplificándola para fines teóricos. Cf. Ibid. I, p. 675. 
La intimidad, el estilo es la profundidad o estructuración de las cosas, es yo como todo en cuanto ejecutándose, es decir, haciéndose carne como mundo del poeta. Es evidente que el nuevo objeto bello, el ciprés-llama, está vivo, está hecho de vida poética, de estilo, y ha unido, transfigurando o desrealizando lo que visual y físicamente parecía imposible. La ley de esta lógica revela que el signo lingüístico no es un órgano al que se le asigna una función, sino que es él mismo órgano funcionando, como cualquier otra cosa que funciona organizándose, es decir, estructurándose, porque se da ejecutivamente, en perspectiva. En las Meditaciones del Quijote, en su teoría del concepto - que he comentado con más detalles en otro lugar- ${ }^{34}$, Ortega, al compás de su idea de perspectiva, aclara que el concepto, más allá de su acepción de idea establecida, como término o coto semántico perfilado en el enramado de la lengua, funciona ejecutiva y perceptivamente en "el escorzo», que define como "órgano de la profundidad visual». Si la vida fuera solo un ver pasivo, asistiríamos a un mero "caos de puntos luminosos», y, sin embargo, nuestra visión es activa, «interpreta viendo y ve interpretando; un ver que es mirar». Visiones son ya ideas, "como bien supo ver Platón», y como dijimos más arriba respecto de Aristóteles, en cuya teoría de la percepción se refleja toda la semántica de la aisthesis, que no es mero sentir, sino percepción sensible, visión de algo concreto, es decir, noética. Si el percepto es ejecutivamente concepto, es este, en todo caso, concluye Ortega, el verdadero órgano de la profundidad.

En el Ensayo de estética, contemporáneo de las Meditaciones, Ortega toma en consideración la estructura de la lengua en su función primariamente narrativa, e indica que hay un subsuelo de imágenes ya conceptualizadas, que poseen su lugar sentimental o perceptivo, que se han hecho fantasmas de sí, pues sirven como formas esquemáticas que nos anclan en un pasado ya vivido; pero, por otra parte, ese fue del esquema vivido se da siempre funcionando

34 Cf. DE Nigris, F., «Mereología, teoría del conocimiento y metafísica de Ortega como fundamento de la Antropología metafísica de Julián Marías», Anales del seminario de Historia de la Filosofía, n³5, 2018 (y, también, «Teoría de la realidad», en MARías, J., Ortega. circunstancia y vocación, op.cit). Órgano y función son dos conceptos fundamentales que recorren toda la obra de Ortega. La idea de "yo» como ejecutividad lleva inevitablemente a Ortega a concluir que el órgano ni siquiera crea la función - o viceversa- sino que se identifica con ella, liberando definitivamente el entendimiento del esquematismo a priori y desembocando en la idea de que mi vida es perspectiva, y de que concepto es ya percepto: «si devolvemos a la palabra percepción su valor etimológico — donde se alude a coger, apresarel concepto será el verdadero instrumento u órgano de la percepción y apresamiento de las cosas» (O.C. I, p. 784). «El escorzo es el órgano de la profundidad visual; en él hallamos un caso límite, donde la simple visión está fundida con un acto puramente intelectual» (Ibid. p. 770). La idea completa la visión, es inseparable de ella: y esto conduce, inevitablemente a que no exista en el hombre aisladamente un ver pasivo, que llevaría solo a un espectáculo de puntos luminosos, sino «un ver activo, que interpreta viendo y ve interpretando; un ver que es mirar. Platón supo hallar para estas visiones que son miradas una palabra divina: las llamó ideas. Pues bien, la tercera dimensión de la naranja no es más que una idea, y Dios es la última dimensión de la campiña» Ibid. 769. 
para la imparable actualidad comunicativa del ahora ${ }^{35}$. Es la función significativa de los esquemas lógicos del concepto, del imaginario narrativo, lo que la metáfora transpone ${ }^{36}$. Esta transposición, sin embargo, no sobreviene al lenguaje, sino que sus mismos conceptos han nacido metafóricamente, así como metafóricamente se definen las cosas: cada una escorzándose en vista de las demás, que nunca llegan a ser un todo, sino perspectiva en que se confirman y fecundan en escorzos continuamente nuevos, posibilitando la creación de otras cosas y del mismo horizonte.

Ahora bien, el arte no se opone metódicamente a la vida, más bien, la perturba argumentalmente, es decir, poéticamente, para generar en ella otros objetos que proyectan el espectador a otro mundo imprevisible, desdoblándole en él, convirtiéndolo en metáfora de sí mismo. De esta suerte el espectador se descubre, en la obra de arte, como un peregrino de mundos que vive entre lo habitual y lo fantástico, porque el artista, con su estilo, ha sabido hacer del propio mundo también el del otro. Por tanto, el arte busca pactos de ficción o - podemos ahora decir- razones metafóricas para subvertir el subsuelo imaginativo de la narración de la vida, desrealizándola, así, según su mismo método. En definitiva, el arte es esencialmente metafórico porque vive transponiendo conceptos, introduciendo a otro mundo que desrealiza al espectador realizándolo fantásticamente, convirtiéndolo en metáfora de sí.

$\mathrm{Y}$ este secreto del arte se revela especialmente en las vanguardias porque en ellas se radicaliza. No es el conceptualismo lo que a fondo las define, sino precisamente su afán de perturbar el concepto establecido, la idea, instalándose, así, en la percepción ejecutiva de la vida, en su razón metafórica, generando escorzos perceptivos que dan lugar a nuevos objetos, que ya son conceptos antes impensables ${ }^{37}$. Más que alimentarse del concepto, entonces, como idea que realiza la cosa o de la cosa como realización de la idea, el arte nuevo busca realizar desrealizando según un estilo, es decir, según nos dijo Ortega en la Deshumanización del arte, «realizar lo irreal en cuanto irreal», la «ficción en sí». El tema poético del arte nuevo, entonces, es el de encontrar razones, pactos o estilos para revelar la ejecutividad de lo figurativo perturbándolo, exaltando el estilo más allá de las cosas que ejecuta, lo que inevitablemente las desfigura y las hace, como diría Levinas, puro exotismo, porque convida al existente a una existencia sin mundo ${ }^{38}$. He aquí, finalmente, la razón vital del

\footnotetext{
$35 \quad$ Ibid. p.672.
}

36 La fecunda diferencia entre esquema lógico y función significativa, alumbrada por Ortega, se encuentra desarrollada por Julián MARías en la Introducción a la filosofía (Revista de Occidente, Madrid, 1947, p.152, 189), como punto de partida de una lógica según la razón vital. Introduzco aquí la metáfora como parte de ella.

37 «Cada nuevo concepto es un nuevo órgano que se abre en nosotros sobre una porción del mundo, tácita antes e invisible. El que os da una idea os aumenta la vida y dilata la realidad en torno vuestro. Literalmente exacta es la opinión platónica de que no miramos con los ojos, sino al través o por medio de los ojos; miramos con los conceptos1. Idea en Platón quería decir punto de vista.» Meditaciones del Quijote, O.C. I, p. 778.

38 Levinas, E., De l'Existence à l'existant, Vrin, Paris, 2004, p. 83ss. 
arte de vanguardia, y, a la vez, la razón histórica de su genialidad: revelar la ejecutividad de la vida, su intrínseca metaforicidad, pues pretende representar, más allá del pensamiento, su puro, poético deciris.

Dicho esto, hay de inmediato que hacer una fundamental advertencia respecto del uso de este recurso artístico, que puede acabar siendo lo contrario de lo que quiso ser: una escolástica del estilo en sí, una búsqueda de originalidad a toda costa, es decir jovialidad injustificada que desemboca en hilaridad, $\mathrm{y}$, finalmente, en altivez y artificialidad, en definitiva, rigidez y formalismo en sus intentos. Este peligro, en efecto, es ínsito a su pretensión cuando se la exaspera, porque si se rompe descontroladamente la habitualidad que requiere la ejecutividad metafórica, se pretende lo imposible: la fantasía sin la imaginación, el percepto sin concepto, la infinitud sin estructura, la completa desrealización de lo que se pretende realizar, en definitiva, deshumanización de «la realidad vivida» sin dejar rastro de lo que la define: «el punto de vista humano». Hay un claro límite en el arte nuevo: «Un cuadro, una poesía donde no quedase resto alguno de las formas vividas, serían ininteligibles, es decir, no serían nada, como nada sería un discurso donde a cada palabra se le hubiese extirpado su significación habitual $»^{40}$.

Quizá en esto consistía esa advertencia, poco aclarada, que Ortega introduce al final de la Deshumanización del arte, justo antes de avisar de que sería imposible en todo caso volver atrás: « QQuien sabe lo que dará de sí este naciente estilo! La empresa que acomete es fabulosa — quiere crear de la nada. Yo espero que más adelante se contente con menos y acierte más» ${ }^{41}$.

Lo puramente metafórico, lo ejecutivo, la perspectiva, no dejan de necesitar imágenes habituales para desrealizar, pues perceptuar es ya conceptuar antes del concebir como idear o teorizar, y, por tanto, la fantasía necesita la imaginación y la deshumanización se funda en la necesaria y forzosa humanización de la vida. Las imágenes tienen que significar para desrealizarse, tienen que haber ganado un lugar habitual en la vida concreta, porque también surgieron des-realizando a otras, transponiéndose en ese continuo sistema abierto de la vida. Esta, en cuanto perspectiva, es la que las está estructurando con un poder de plasticidad sin límites, fuente de su virtualidad viva. La figuración y la ejecutividad, como el proyecto y la circunstancia, son inseparables.

$\mathrm{Si}$ «El arte es esencialmente IRREALIZACIÓN» y si dentro de ella "podemos clasificar las tendencias diversas en idealistas y realistas», esto, concluye

39 «La narración hace de todo un fantasma de sí mismo, lo aleja, lo traspone más allá del horizonte de la actualidad. Lo narrado es un "fue". Y el fue es la forma esquemática que deja en el presente lo que está ausente, el ser de lo que ya no es - la camisa que la sierpe abandona. Pues bien, pensemos lo que significaría un idioma o un sistema de signos expresivos de quien la función no consistiera en narrarnos las cosas, sino en presentárnoslas como ejecutándose. Tal idioma es el arte: esto hace el arte. El objeto estético es una intimidad en cuanto tal —es todo en cuanto yo.» Ensayo de estética a manera de prólogo, O.C. I, p.672.

40 O.C. III, p. 856.

$41 \quad$ Ibid. p. 877. 
Ortega, es siempre posible «sobre el supuesto ineludible de que es la esencia del arte creación de una nueva objetividad nacida del previo rompimiento y aniquilación de los objetos reales» ${ }^{42}$. Y si la metáfora es el medio ejecutivo creador para expresar lo inexpresable, el que perturba nuestra visión natural de las cosas, su significación habitual, para otorgarle otro valor perceptivosentimental, significa, entonces, que «son, pues, la superación o rompimiento de la estructura real de éstas, y su nueva estructura o interpretación sentimental, dos caras de un mismo proceso ${ }^{43}$.

En definitiva, el estilo poético del arte nuevo revela el poder originario de nuestra vida de crear mundos, fantasía ilimitada, pero con un límite imaginativo que da sentido a la plasticidad fantástica y la justifica como tal: que la creación de mundo es inevitable creación de su personaje, en quien el espectador se transfigura convirtiéndose, según dijimos, en metáfora de sí. ¿No habría así confirmado Ortega en la deshumanización del arte nuevo que el proyecto de la vida es intrínseca humanización?

\section{El ESTILO DE AdÁn, PRIMER ARTISTA y PRIMERA OBRA DE ARTE}

Realismo, nos dijo Ortega, estriba en establecer una idea de las cosas según la cual estas funcionan como reales, desvelando lo que verdaderamente son, su aspecto fundamental. Realismo es idealismo, una ficción de realidad derivada de una doctrina del conocimiento fundada en el «ser»: predicación de la physis a cuyo lógos el hombre también participa, de ahí que su intelecto coincide con las formas naturales, su idea es eîdos, perfecta adecuación. Si Ortega, en $L a$ Idea de Principio en Leibniz, una de las más profundas críticas a esta lógica a lo largo del siglo veinte ${ }^{44}$, define el ser como transcendental abstracto de la mente griega que rehúye del sentido originario de las cosas como pragmata, ya desde Adán en el Paraíso, también inspirándose en Leibniz y en una tendencia que divisa desde por lo menos el Renacimiento, concibe que el ser de las cosas, su «esencia» o "vida», no es más que su sistemático relacionarse unas con otras, es decir, «un sistema de movimientos». "La vida de una cosa es su ser. ¿Y qué es el ser de una cosa? Un ejemplo nos lo aclarará. El sistema planetario no es un sistema de cosas, en este caso de planetas: antes de idearse el sistema planetario no había planetas. Es un sistema de movimientos; por tanto, de relaciones: el ser de cada planeta es determinado, dentro de este conjunto de relaciones, como determinamos un punto en una cuadrícula [...] cada elemento del sistema necesita de todos los demás: es la relación mutua entre los otros. Según esto, la esencia de cada cosa se resuelve en puras relaciones.

$42 \quad$ O.C. I, p. 678.

43 Ibid.

${ }_{44}$ La otra, y con continuos paralelismos argumentales, desde mi punto de vista, es Autrement qu'être ou au-delà de l'essence, de Levinas. 
[...] Y como la relación no es una res, sino una idea, la filosofía moderna se llama idealismo, y la medieval, que empieza en Aristóteles, realismo. [...] Cada cosa una encrucijada: su vida, su ser es el conjunto de relaciones, de mutuas influencias en que se hallan todas las demás. Una piedra al borde de un camino necesita para existir del resto del Universo ${ }^{45}$. Ahora bien, la ciencia, dice Ortega a continuación, alejándose de todo racionalismo moderno, "se afana por descubrir ese ser inagotable que constituye la vitalidad de cada cosa. Pero el método que emplea compra la exactitud a costa de no lograr nunca del todo su empeño.». He aquí el punto de partida de Ortega respecto de la tradición: el «ser inagotable» como «vida» de las cosas y su «esencia» como «puras relaciones», lo que equivale a decir que tanto aquel como esta se hacen de movimiento, que consisten en individualidad. En efecto, no se trata de que el ser sea mera relación, al estilo de categoría aristotélica, o en el sentido de la armonía preestablecida leibniziana, o, incluso, de los esquemas kantianos como determinaciones a priori de tiempo. En estos casos se establece que el ser (sea sustancia, mónada o síntesis transcendental) cuenta con funciones a priori que prevén la conexión orgánica de sus partes, de sus relaciones, mas, así, los relatos pierden su vitalidad contingente, ejecutiva. Como querrá remarcar Ortega en dos notas añadidas en $1915^{46}$, el órgano se hace en la misma función (es «coetáneo»), siendo esta la que adquiere la cosa en el movimiento de su inagotable relacionarse con las demás, es decir, como «vida». Las verdades de razón, habría que concluir, son las de hecho, y el valor de las cosas, su contingencia. Nos lo explica Ortega con un ejemplo ulterior - que recuerda el del cordero y el águila en la Genealogía de la moral de Nietzsche-. El valor de la tierra para el labriego consiste en "pisar la rojiza piel del planeta y arañarla con el arado», mientras para el astrónomo en «determinar exactamente el lugar que ocupa el globo en cada instante» ${ }^{47}$. Es la necesidad de cada uno la que genera un punto de vista que realiza la cosa, de ahí que el ser de esta — de la tierra, en este ejemplo-, es infinita, inagotable, al igual que su valor. Estas conclusiones finalmente versan sobre el arte realista, estímulo filosófico primigenio de

\footnotetext{
45 O.C. II, p. 66.
}

46 En ellas Ortega confirma su pretensión de sustraer las cosas del nivel ontológico del conocimiento, de la razón científica abstracta, para insertarlas en la vitalidad de su espontáneo e inagotable relacionarse entre sí, que, en principio, como vamos a ver, el arte ayuda a captar. Recuérdese, de la Deshumanización del arte, que «la forma primigenia de una manzana es la que ésta posee cuando nos disponemos a comérnosla» o que «El martillo es la abstracción de cada uno de sus martillazos» es, decir, su «vida espontánea», se afirma en las Meditaciones del Quiote (O.C. I, 756), donde se impondrán definitivamente los conceptos de «estructura» y «sistema» (Cf. DE NigRIs, F., op. cit.). Hablar de un paradigma kantiano en Ortega, como lamentablemente se ha hecho, significa, una vez más, desconocer el sentido de su doctrina, que pasa ahora por comprender este aspecto fundamental y definitivo para toda su obra: que las cosas están hechas de vida. No se olvide, además, como ya comentamos, la influencia de Von Uexküll, según el cual es el plan de vida — proyecto para Ortega- que genera su entorno, es decir, la funcionalidad de su organicidad.

47 O.C. II, p. 60. 
Ortega. La imitación es imposible, porque no existe «una realidad inmutable y única con quien poder comparar los contenidos de las obras artísticas. Hay tantas realidades como puntos de vista. El punto de vista crea el panorama ${ }^{48}$. Lejos de ser totalizable, el ser es «inagotable», realización infinita de cada cosa en el movimiento generado por todas; en otras y postreras palabras, "todo ejecutándose», "perspectiva». Y anticipando también la equiparación entre percepto y concepto o del «ver como interpretar» de las Meditaciones, termina afirmando Ortega en ese párrafo que «Ver y tocar las cosas no son, al cabo, sino maneras de pensarlas».

La ciencia no se interesa en la vida de las cosas, en «su ser inagotable», sino que las define clausurándola en un sistema determinado de relaciones exigido por las necesidades de exactitud y generalidad de su método. No es lo mismo «esta piedra venerable del Guadarrama», piedra íntima para Ortega, que una piedra como «un caso particular de una ley general. La ciencia convierte cada cosa en un caso, es decir, en aquello que es común a esta cosa con otras muchas. Esto es lo que se llama abstracción: la vida descubierta por la ciencia es una vida abstracta, mientras, por definición, lo vital es lo concreto, lo incomparable, lo único. La vida es lo individual $»^{49}$. La ciencia «resuelve el primer estadio del problema de la vida», es decir, el plano reflexivo que busca definiciones generales para dominar las cosas, para saber cómo actuar respecto de ellas, incluso cuando sus exigencias son morales. Esta lógica, en efecto, pertenece tanto a las ciencias naturales, que definen las cosas como «vida material», como a las ciencias del espíritu, que las entiende como "vida psíquica», de ahí que también cuando buscamos saber qué es la alegría o la tristeza, se somete estas «al método de abstracción», que busca agotar o acotar su ser ${ }^{50}$. El problema de la ciencia, afirma definitivamente Ortega para toda su doctrina, es que ha solido reducir «el significado de la palabra vida a una disciplina particular: la biología» de ahí que las cosas han sido siempre vistas desde la abstracción, la parcialidad ${ }^{51}$. Sin embargo, «es menester que las cosas sean algo más que cosas.

48 Ibid. Esta idea del valor como potencia infinita de realizarse las cosas en vista del quehacer del hombre se enriquecerá de ahí a poco con la teoría de los valores de Scheler, si bien manteniendo algunos rasgos fundamentalmente diferente por la distancia entre la idea de "yo» como «mi vida» en cuanto proyecto de salvación circunstancial y la dicotomía del alemán entre persona-acto y yo-entorno. A pesar de la divulgación del pensamiento de Scheler que ha llevado a cabo Ortega —en línea con su vocación para con España y su labor con la Revista de Occidente-, nunca en su pensamiento original llegará a admitir una función de las cosas como bienes portadores de valores eternos que históricamente en ellas se revelan; tampoco admitirá — como Scheler en Ordo Amoris - que mirar desde los valores es ver desde el ojo divino. Quede esto aquí solo y muy parcialmente señalado.

49 O.C. II, p. 66.

50 Cf. Ibid. p. 67.

$51 \quad$ Ibid. p. 65. Hasta aquí se limita la inspiración nietzscheana, que casi siempre tiende a una idea biológica de vida, dominada por impulsos, tendencias, acciones individuales cuyo fondo es insondable para la conciencia, que, por su parte, es naturaleza común y secundaria en el hombre. Cf. también, de 1910, todo el apartado titulado «El hombre no es individuo biológico» en La pedagogía social como programa político. De ahí esta cita: "Cuando hablamos, 
Napoleón no es solo un hombre, un caso particular de la especie humana: es este hombre único, este individuo. Y la piedra de Guadarrama es distinta a otra piedra químicamente idéntica que yaciera sobre los Alpes ${ }^{52}$.

¿Qué saber se ocupará de las cosas en su «ser inagotable» y alumbre el problema al que responden las necesidades de «lo vital», de «lo concreto», «incomparable», «único», es decir, de la vida «individual», no biológica? Si incluso la filosofía, como hemos anticipado, ha buscado la exactitud de la forma, del ser como aspecto fundamental, ¿qué saber podrá inspirarla de nuevo e instalarla en una razón que comprende la vida, en cuanto vida ejecutivamente biográfica, «realidad radical» en que radican en perspectiva, de forma única, concreta e inagotable, todas las demás realidades?

«El hombre lleva dentro de sí un problema heroico, trágico: cuanto hace, sus actividades todas, no son sino funciones de ese problema, pasos que da para resolver ese problema. Es éste de tal calibre, que no hay manera de darle batalla campal: siguiendo la máxima divide et impera, el hombre lo secciona y lo va resolviendo por partes y estadios. La ciencia es la solución del primer estadio del problema; la moral es la solución del segundo. El arte es el ensayo para resolver el último rincón del problema» ${ }^{53}$. En efecto, «De la tragedia de la ciencia nace el arte. Cuando los métodos científicos nos abandonan, comienzan los métodos artísticos. Y si llamamos al científico método de abstracción y generalización, llamaremos al del arte método de individualización y concretación [...] y el problema del arte es lo vital, lo concreto, lo único en cuanto único, concreto y vital. [...] De aquí que el mundo natural, producto de la ciencia, sea elaborado mediante generalizaciones, al paso que este nuevo mundo de la pura vitalidad, para construir el cual nació el arte, haya que crearlo mediante la individualización» ${ }^{54}$.

El arte pretende resolver el problema heroico, trágico del hombre sin segmentarlo como hace la ciencia, sino explorándolo en su vida concreta, a partir de su mundo, hecho de «pura vitalidad». Este mundo no se produce por abstracción, sino que se «crea mediante individualización». ¿Pero qué significa esta fundamental expresión del método del arte que pretende instalarse en el mismo método de la vida y, por tanto, asumir su pacto originario de ficción, atender a sus necesidades espontáneas y, en definitiva, responder al problema que la anima en cuanto vida humana? Ortega vuelve una vez más sobre los conceptos de realismo e idealismo, que cree gravemente desorientadores para el arte, aclarándolos con una radicalidad de la que se alimentará toda su doctrina.

por tanto, de educar a un hombre no nos referimos a esa imagen corpórea y discontinua del individuo biológico. La fisiología del antropoide es sólo un pretexto para que exista el hombre, como la rama nudosa del árbol es sólo un pretexto para que aposado en ella dé el pájaro su canto». Ibid. p. 93.

52 Adán en el Paraíso, Ibid. p. 67.

$53 \quad$ Ibid. p. 63.

$54 \quad$ Ibid. p. 68. 
Inspirándose en Cézanne, afirma que «realizar» consiste en «convertir en cosa lo que por sí mismo no lo es ${ }^{55}$. A continuación, indica que el realismo en arte ha solido entenderse como un ejercicio que busca la copia de una cosa, sin embargo, «sabemos que una cosa no es lo que vemos con los ojos», es decir, no consiste en su ser como aspecto fundamental y definitivo que, una vez copiado, nos proporciona la imitación de la cosa; al contrario, «para producir una cosa, una res, forzosamente necesitamos de todas las demás. Realizar, por tanto, no será copiar una cosa, sino copiar la totalidad de las cosas, y puesto que esa totalidad no existe sino como idea en nuestra conciencia, el verdadero realista copia sólo una idea: desde este punto de vista no habría inconveniente en llamar al realismo más exactamente idealismo» ${ }^{56}$.

El método del arte, que busca seguir el de la vida, y al que Ortega inspira su filosofía, no consiste en reproducir cosas sino en «realizarlas» en el sentido de hacer cosa lo que antes no lo era, porque, en rigor, la cosa no «es», sino va siendo o, mejor dicho, se hace: se revela generando su propia ficción mundana, se muestra solo potenciándose o vivificándose en el entramado sin fin de las conexiones que va adquiriendo con las demás; en otras palabras, el mundo mismo, "pura vitalidad», se "crea mediante individualización».

En 1914 Ortega resumirá este análisis con un ejemplo que se repetirá a lo largo de toda su doctrina: de una naranja que veo, en realidad, veo solo la mitad, la otra mitad, sin embargo, se incorpora a la mitad vista, porque ver es siempre interpretar, porque percepto es concepto, perspectiva, radicación real de la realidad, en definitiva, "crear por individuación». Y la perspectiva, ya hemos visto, es realización metafórica, revelar ejecutivamente las cosas en vista de las otras, de ahí que a la naranja le va la circunstancia entera haciéndose, es decir, históricamente, y, por tanto, mi cuerpo en ella, biográficamente ${ }^{57}$. Y "Cuando dice el hombre de mucha fe que ve a Dios en la campiña florecida y en la faz combada de la noche, no se expresa más metafóricamente que si hablara de haber visto una naranja». En efecto, ver a Dios en la campiña o la naranja en la mitad que veo, es exactamente lo mismo, transponer una cosa en otra, realizarla así como realiza la tierra el labriego o el astrónomo, es decir, crear un mundo virtual, ficción de totalidad, desde el propio estilo. Y sustraer una cosa de la perspectiva, significa convertirla en nada ${ }^{58}$.

Ortega aclara con tal radicalidad, desde 1910, que el pacto de ficción del realismo es el mismo que el de su idealismo especular: creer en el ser de las cosas como eîdos del que los eide fácticos se componen o derivan sintéticamente; lo que equivale a creer que las cosas se realizan originaria y verdaderamente desde una epistemología del pensar, no del vivir, fundada en el ser como idea de totalidad, sin percatarse, además, de que solo se trata de un ideal de realización de las cosas entre los infinitos posibles. Pero, lo más grave es que

\footnotetext{
$55 \quad$ Ibid. p. 69.

56 Ibid. p. 70.

57 O.C. I, p. 769. Cf. supra nota 34.

$58 \quad$ Ibid. p. 766.
} 
habiéndose ocupado la filosofía de totalizar la aspectualización o realización de las cosas, adecuándose a un aspecto fundamental de ellas, ha prescindido de estudiar la razón de la ejecutividad de la vida, esto es, de la realización por individualización. Se ha abstenido la filosofía, en otras palabras, de pensar la verdad de la vida, su razón vital, como razón de infinitud ${ }^{59}$. La ciencia del ser, entonces, sería una razón abstracta y la ontología tradicional, el modelo primigenio de las ciencias que funda su ideal de exactitud y generalización; su método, que responde a una peculiar interpretación de la corporeidad humana, es visión noética, o, da lo mismo, intuición categorial, en suma, intuir las cosas significándolas en el lógos de la physis, en el kósmos ${ }^{60}$.

La ingenuidad de la fenomenología, que ha llevado a Husserl a la práctica de la epokhé, ha sido interpretar el ser como creencia que es menester investigar en su génesis activa y pasiva porque en ella se funda la razón, en cuanto razón de la conciencia intencional ${ }^{61}$. Planteada así la racionalidad, como teoría del ser, se fundan en ella sus demás dimensiones — práctica y axiológica— porque las cosas, si bien fácticamente aspectualizadas, se hacen eidéticamente adecuadas como síntesis de individuación, es decir, se hacen términos estables de praxis y portadoras de valores. El camino de Ortega es radicalmente diferente: explora las pretensiones del realismo en el arte a partir de la vida individual y concreta, descubriendo que copiar una cosa es tarea irrealizable que obliga a generar una idea de ella, de su aspecto fundamental, de ahí que eîdos es idea, realismo es idealismo, siempre creación de un ideal. Lejos de atenerse a ese ideal como criterio de verdad, Ortega — como vamos a ver a continuación siguiendo el análisis de Adán en el Paraíso - propone remontarse positivamente a la forzosa tarea virtualizadora de la vida, a su originaria e imparable creación de un «mundo virtual», de una «ficción de totalidad» en que las cosas se realizan individualmente. Ese mundo virtual es inagotable, es una «como infinitud» en que se revela «la forma de la vida». La misión de la filosofía, sugerida por el arte, es captar la razón de la infinitud, del ser inagotable de las cosas, lo que equivale a decir, captar esa forma

59 Esto confirmaría, cómo afirma Julián MARías en la Introducción de la filosofía (1947), que la filosofía en su nacimiento es pretensión filosófica que se hace con método científico, pues su idea de realidad - la physis - no es más que un horizonte ficticio de exactitud susceptible de ser matematizado.

${ }_{60}$ Si Husserl se hubiera percatado de la gravedad de afirmar la infinitud de las ontologías materiales, habría tenido que reformular o, mejor dicho, suspender, la síntesis de individuación como método y plantearse la razón de la infinitud. Pero ello hubiese significado renunciar a todo método primariamente adecuacionista y, en última instancia, a la conciencia intencional como correlación noético-noemática.

${ }_{61}$ Recuérdese el aserto fundamental de la fenomenología de la razón de Ideen I: «Wahrheit ist offenbar das Korrelat des vollkommenen Vernunftcharakters der Urdoxa, der Glaubensgewißheit». Ideen I, (Hua, III, 2), p. 290; que no es otra cosa que su interpretación madura de la fórmula brentaniana - repetida en las Logische Untersuchungen - según la cual todo acto intencional es una representación o se funda en una representación. Cf. DE NIGRIS, F., «Intencionalidad, pasividad y autoconciencia en la fenomenología de Husserl», Ideas y Valores, 64 (157), 2015, pp. 215-250. 
que no es realizable desde el punto de vista de la ontología clásica, porque es la razón por la cual la vida está comprometida a ejecutarse circunstancialmente, es decir, a realizar infinitamente las cosas, a crearlas por individualización. En otras palabras, la razón filosófica busca explorar la ejecutividad de la vida como continua realización de infinitas formas históricas, pero remontándose, todas, a una forma que revela el sentido originario de su teoría, aquella que la convierte en práctica creadora y creativa. Ortega, desde 1910, se inspira en el arte porque asume que a diferencia de las ciencias o de la ontología clásica, no rehúye de la ficción intrínseca de la vida, sino que la asume para ofrecernos sin afán de exactitud, «infinitas perspectivas» que revelan cuál es «la forma de la vida», es decir - retomando nuestra terminología-, la idea o pacto de ficción que la vida humana genera para responder forzosa y continuamente a su problema general, trágico y heroico, a su tema poético radical que, de esta suerte, justifica un organismo humano, fuente de toda técnica porque movimiento inseguro, dramático, carnal.

«¿Cómo poner de manifiesto la totalidad de relaciones que constituye la vida más simple, la de este árbol, la de esta piedra, la de este hombre? De un modo real es esto imposible; precisamente por esto es el arte ante todo artificio: tiene que crear un mundo virtual. La infinidad de relaciones es inasequible; el arte busca y produce una totalidad ficticia, una como infinitud. Esto es lo que el lector habrá experimentado cien veces ante un cuadro ilustre o una novela clásica; nos parece que la emoción recibida nos abre perspectivas infinitas e infinitamente claras y precisas sobre el problema de la vida. El Quijote, por ejemplo, deja en nosotros, como poso divino, una revelación súbita y espontánea que nos permite ver sin trabajo, de una sola ojeada, una anchísima ordenación de todas las cosas: diríase que de pronto, sin previo aprendizaje, hemos sido elevados a una intuición superior a la humana ${ }^{62}$. Por consiguiente, lo que debe proponerse todo artista es la ficción de la totalidad; ya que no podemos tener todas y cada una de las cosas, logremos siquiera la forma de la totalidad. La materialidad de la vida de cada cosa es inabordable; poseamos, al menos, la forma de la vida» ${ }^{63}$.

«La materialidad» - así como la espiritualidad— no es más que otra idea, otra ficción que ha asumido el realismo artístico para realizar las cosas. Toda idea nos remite a una razón o problema al que «la forma de la vida» responde. Esta tampoco, y con mayor razón, es una idea como esencia, imagen o figura de un todo definido. Lograr esto «de un modo real es imposible», y sería recaer ingenuamente en la ficción del ser realista o idealista. Más bien, como nos desveló el mimo o, por su parte, el arte nuevo, hay que aceptar la ficción en que consiste la vida y buscar métodos de ficción cuando se pretende comprenderla. No hay una forma de la vida como si hubiera un eîdos de una cosa que agotara todas sus manifestaciones espaciales, reduciéndola, en realidad, a la nada. La

62 Esta es la razón por la que Ortega escribirá las Meditaciones del Quijote para explorar el problema de la vida. Es un libro que es "selva de ideas» y, sobre todo, es el estilo de Cervantes el que crea el Quijote como Cristo español, es decir, nuevo Adán que puede salvar al hombre español de su circunstancia y, además, ofrecer una nueva idea de la vida.

$63 \quad$ Ibid. p. 68. 
aspectualización, y por tanto el tiempo, es lo que revela la idea como escorzo elegido que define, por el pacto de ficción de su ciencia, su objeto de estudio, así como la astronomía decide en todo momento que hay planetas con su peculiar método de realización. Por tanto, cuando hablamos de «la forma de la vida», significamos tantas formas como las «perspectivas infinitas» que pretenden interpretarlas, es decir, vivirlas individual o personalmente. Mas esto quiere decir, precisamente, que la forma de la vida que buscan las humanidades y radicalmente la filosofía, es el problema mismo que hace que la vida se haga ejecutivamente como realidad radical, porque no la agota, sino que es lo que la compromete a realizarse individualmente, "a crear por individualización», a hacer que sea, en definitiva, mi vida.

¿Cuál será, entonces, el problema de la vida, que no agota esta en una forma o ser definitivo, imposible de lograr, sino precisamente en su radical ideal de realización, en constitutiva ficción que genera un «mundo virtual», una «infinitud» en que se potencian o vivifican todas las cosas, ejecutándose y revelándose en perspectiva? ¿Qué o quién es lo que convierte la vida en proyecto? «El hombre es el problema de la vida», responde Ortega ${ }^{64}$. El problema de mi vida, lo que la convierte en quehacer o forzosa ejecución, no es otro que yo mismo en cuanto hombre, porque tengo continuamente que elegir al personaje de mi vida, esto es, elegir al hombre que individualmente soy. Es este el pacto de ficción que compromete mi vida a realizarse fáctica y dramáticamente, es decir, entendemos ahora, humanamente. Y esta es la razón metafórica que nos hace a nosotros mismos peregrinos de mundos, porque nos transponemos virtualmente en el hombre, realizándolo individualmente.

Mi vida como realidad radical es razón de individualización del hombre, creación de humanidad por individualización; en otras palabras, el hombre es el tema poético de la vida que inspira, como necesidad radical, todas las necesidades del arte y sus múltiples estilos líricos. "Cada arte nace por diferenciación de la necesidad radical de expresión que hay en el hombre, que es el hombre» ${ }^{6}$. He aquí el preciso significado de las expresiones "punto de vista humano» o de «la realidad vivida» de la Deshumanización del arte, así como la genialidad y la caducidad histórica del arte de vanguardia, que vive —entendemos ahora-deshumanizando la intrínseca pretensión humanizadora de mi vida.

64 Ibid. p. 65. En 1906 Ortega ya habla de la «idea sobreexistencial y salvadora del arte», de la «intención metafísica en su elaboración», de que es, en definitiva, "una subrogación de la vida». En 1911 — sin que aquí podamos comentarlo en detalle_ indicará que Adán en el Paraíso tiene gran parecido con el libro de Worringer en que se vincula cada arte a un tipo de hombre, como formas reveladoras de la vida de una época. Allí dirá que «La religión y la poesía no pretenden ellas suplantar esa vida, sino que la sirven y diaconizan. ¿No es esto discreto? La religión y la poesía son para la vida». Los «tipos de hombres» será un tema de estudio continuo en Ortega; baste ver Meditaciones sobre la técnica, cuyo tema y nivel teórico es un claro desarrollo de todo lo que aquí estoy analizando de las primeras obras de Ortega respecto del arte de la vida como fuente última de la técnica.

65 O.C. II, p. 63. 
Las necesidades de la vida transcienden la materia de la ciencia y remiten todas al problema del hombre, en función del cual se hace su organismo como carne. En efecto, si la función crea el órgano (lo que más bien quiere decir, es órgano), y la función la crea la necesidad, esta, dice Ortega, es a su vez creada por el problema ${ }^{66}$. Y si el problema de la vida es el hombre mismo, significa que vivir es el drama de quien tiene que hacer personalmente el hombre: yo como mi vida, mi persona. «Las piedras, los animales viven: son vida», pero, afirma Ortega, utilizando una categoría fundamental de toda su doctrina, «no se percatan» de ello. Y no es que le falte conciencia despierta; esta puede fallarle también al hombre; la diferencia estriba en el sentido de la vida, que para el animal no significa hacer la propia animalidad. «El animal desarrolla sus miembros por propio impulso; siente dolor, desarrolla sus miembros: él es esta su vida. La piedra yace sumida en un eterno sopor, en un sueño denso que pesa sobre la tierra: su inercia es su vida, es ella. Pero ni la piedra ni el animal se percatan de que viven». Sin embargo, cuando Dios dijo « «Hagamos el hombre a nuestra imagen». El suceso fue de enorme trascendencia [...] Cuando Adán apareció en el Paraíso, como un árbol nuevo, comenzó a existir esto que llamamos vida. Adán fue el primer ser que, viviendo, se sintió vivir. Para Adán la vida existe como un problema.» Mundo es vida, que consiste en el problema del hombre. No se trata, por tanto, de que al hombre le vaya su propio ser, como dirá Heidegger diecisiete años después, sino de que al hombre le va el hombre mismo como problema, razón por la cual la vida es proyecto ${ }^{67}$.

El individuo humano no «es», no «existe», no le va su propio ser y, por tanto, el ser en general, sino que vive, lo cual quiere decir que le va el hombre mismo, y que tiene que hacerlo haciéndose en él, como razón de la ejecutividad de su vida, que es lo que la convierte en un quehacer, en una historia. Y si al hombre le va el hombre mismo como problema, todos sus órganos serán funciones de ese problema, lo que equivale a decir un cuerpo humano, no instintivo, sino biográfico, porque es un cuerpo que en cada individuo está haciendo el hombre, como forma o potencia virtual de su vida. En definitiva, Adán en el paraíso significa la aparición de la realidad misma porque en la vida se revela la razón de la creación en la criatura: el problema infinito del hombre que se hace en cada hombre, el pacto de ficción o razón metafórica del individuo en la humanidad. «Cuando Adán apareció en el Paraíso, como un árbol nuevo, comenzó a existir esto que llamamos vida. Adán fue el primer ser que, viviendo, se sintió vivir. Para Adán la vida existe como un problema. [...] Adán en el Paraíso es la pura y simple vida, es el débil soporte del problema

\footnotetext{
66 Ibid.

67 Esta diferencia fundamental, así como otras que se refieren a la razón de apertura de un tiempo biográfico de la vida (en vez de un tiempo como sentido del ser), no se han divisado en obras que han intentado reducir el pensamiento de Ortega al de Heidegger. Cf. entre otros, Morón Arroyo, C., El sistema de Ortega y Gasset, Alcalá, Madrid, 1968. Sirva también Morón Arroyo como ejemplo de un conjunto de interpretes que no ven Adán en el Paraíso más que un «pecado de juventud» respecto del cual, obras maduras dan un giro diametral.
} 
infinito de la vida» ${ }^{68}$. Adán es «yo», «mi vida», inseparable del Paraíso, su circunstancia, proyectándolo o ejecutándolo como historia reveladora de su misión de humanidad. «La gravitación universal, el universal dolor, la materia inorgánica, las series orgánicas, la historia entera del hombre, sus ansias, sus exultaciones, Nínive y Atenas, Platón y Kant, Cleopatra y Don Juan, lo corporal y lo espiritual, lo momentáneo y lo eterno y lo que dura..., todo gravitando sobre el fruto rojo, súbitamente maduro del corazón de Adán. ¿Se comprende todo lo que significa la sístole y diástole de aquella menudencia, todas esas cosas inagotables, todo eso que expresamos con una palabra de contornos infinitos, VIDA, concretado, condensado en cada una de sus pulsaciones? El corazón de Adán, centro del universo, es decir, el universo íntegro en el corazón de Adán, como un licor hirviente en una copa. Esto es el hombre: el problema de la vida ${ }^{69}$. Si el animal, como dirá Ortega a lo largo de toda su obra, no tiene como problema su animalidad, al hombre le va su propia humanidad, de ahí que respecto de aquel no tiene naturaleza sino historia. Adán es, como sugiere este término de tradición semítica, la humanidad y el individuo, aquella haciéndose en este, historizándose o metaforizándose en cada cual, a diferencia de la vida animal, en que la animalidad no se hace, sino se revive de nuevo en cada animal. «La única diferencia radical entre la historia humana y la «historia natural» es que aquélla no puede nunca comenzar de nuevo. [...] Parejamente, el tigre de hoy es idéntico al de hace seis mil años, porque cada tigre tiene que empezar de nuevo a ser tigre, como si no hubiese habido antes ninguno. El hombre, en cambio, merced a su poder de recordar, acumula su propio pasado, lo posee y lo aprovecha. El hombre no es nunca un primer hombre; comienza desde luego a existir sobre cierta altitud de pretérito amontonado.[...] El verdadero tesoro del hombre es el tesoro de sus errores, la larga experiencia vital decantada gota a gota en milenios» ${ }^{70}$.

\section{OBRAS CITADAS}

Cerezo Galán, P. (1984). La voluntad de Aventura. Aproximación crítica al pensamiento de Ortega y Gasset. Barcelona: Ariel.

De Nigris, F. (2018). «Mereología, teoría del conocimiento y metafísica de Ortega como fundamento de la Antropología metafísica de Julián Marías», Anales del seminario de Historia de la Filosofía, no 35.

FrancK, D. (1981). Chair et corps. Paris: Les éditions de Minuit.

GiLson, E. (1959). Painting and reality. New York: Pantheon Books.

Husserl, E. Ideen zu einer reinen Phanomenologie und phanomenologischen Philosophie. Allgemeine Einfuhrung in die reine Phanomenologie [Ideen I und II]. Hua III und IV. Den Haag: Martinus Nijhoff, 1950-1952.

Levinas, E. (2004). De l'Existence à l'existant. Paris: Vrin.

${ }^{68} \quad$ Ibid. p. 65

69 Ibid.

70 Prólogo para franceses, O.C.IV p. 369. Cf, en detalle, Historia como sistema. 
- (1971). Totalité et infinie. Paris: Kluwer Academic.

- (1978). Autrement qu'être ou au-delà de l'essence. Paris: Kluwer Academic.

Marías, J. (1982). Introducción a la filosofía, Obras, Tomo II. Madrid: Revista de Occidente.

- (1982). Ortega. circunstancia y vocación, Obras, IX. Madrid: Revista de Occidente.

Marion, J.-L. (1997). Étant donné. Essai d'une phénoménologie de la donation. Paris: Presses Universitaires de France.

Morón Arroyo, C. (1968). El sistema de Ortega y Gasset. Madrid: Alcalá.

Merleau-Ponty, M. (1964). Le visible et l'invisible. Paris: Gallimard.

Ortega y Gasset, J. (2006). Obras Completas, Tomos I-X. Madrid: Taurus.

SiLver, P. (1973). "La estética de Ortega», NRFH, vol. 22, n. 2.

Universidad Pontificia Comillas, Madrid

fdenigris@icade.comillas.edu

Francesco DE Nigris

[Artículo aprobado en septiembre de 2019] 